\title{
Uremic Toxins and Vascular Calcification-Missing the Forest for All the Trees
}

\author{
Nikolas Rapp ${ }^{1}$, Pieter Evenepoel ${ }^{2}$, Peter Stenvinkel ${ }^{3}$ and Leon Schurgers $1, *$ (I) \\ 1 Department of Biochemistry, Cardiovascular Research Institute Maastricht (CARIM), Maastricht University, \\ 6229 ER Maastricht, The Netherlands; n.rapp@maastrichtuniversity.nl \\ 2 Laboratory of Nephrology, KU Leuven Department of Microbiology and Immunology, \\ University Hospitals Leuven, 3000 Leuven, Belgium; pieter.evenepoel@uzleuven.be \\ 3 Karolinska Institute, Department of Clinical Science, Intervention and Technology, \\ Division of Renal Medicine, 14186 Stockholm, Sweden; peter.stenvinkel@ki.se \\ * Correspondence: 1.schurgers@maastrichtuniversity.nl
}

Received: 9 September 2020; Accepted: 25 September 2020; Published: 29 September 2020

\begin{abstract}
The cardiorenal syndrome relates to the detrimental interplay between the vascular system and the kidney. The uremic milieu induced by reduced kidney function alters the phenotype of vascular smooth muscle cells (VSMC) and promotes vascular calcification, a condition which is strongly linked to cardiovascular morbidity and mortality. Biological mechanisms involved include generation of reactive oxygen species, inflammation and accelerated senescence. A better understanding of the vasotoxic effects of uremic retention molecules may reveal novel avenues to reduce vascular calcification in CKD. The present review aims to present a state of the art on the role of uremic toxins in pathogenesis of vascular calcification. Evidence, so far, is fragmentary and limited with only a few uremic toxins being investigated, often by a single group of investigators. Experimental heterogeneity furthermore hampers comparison. There is a clear need for a concerted action harmonizing and standardizing experimental protocols and combining efforts of basic and clinical researchers to solve the complex puzzle of uremic vascular calcification.
\end{abstract}

Keywords: uremic toxins; uremia; chronic kidney disease; cardiovascular disease; vascular smooth muscle cells; vascular calcification; middle molecules; protein bound uremic solutes; water-soluble uremic solutes

Key Contribution: A large fraction of the uremic toxins has not been investigated towards vascular calcification; and research in this direction suffers from a low degree of standardization. We put forward the approach to test effects of URM on VSMC in relation to VC more systematically and advocate for more CRS centered research.

\section{Relevance and Objective}

Chronic kidney disease (CKD) is recognized as a major non-communicable disease of growing epidemic dimension worldwide. The prevalence of CKD has increased by $19.6 \%$ between 2005 and 2015 [1] and reaches an overall global level of 11-13\% [2]. Up to 70\% of the healthcare cost related to CKD are due to hospitalization [3], the majority of which is accounted for by cardiovascular events [4]. The risk for cardiovascular disease (CVD) related hospitalization or death has been shown to increase with progression of CKD [5]. Dialysis increases cardiovascular mortality by up to 20-fold [6]. The reciprocal detrimental effects of the cardiovascular (CV) system and the kidneys on each other has been termed cardiorenal syndrome (CRS). CRS can be classified in five types according to duration and aetiology, namely: acute CRS, chronic CRS, acute renocardiac syndrome, chronic renocardiac 
syndrome and secondary CRS. CRS type 4, the chronic renocardiac syndrome, describes CKD leading to CVD [7]. While traditional Framingham risk factors like dyslipidaemia and diabetes contribute to CVD, they cannot fully explain the excessive mortality observed in patients with CRS type 4 . Non-traditional risk factors including inflammation, oxidative stress or abnormal calcium-phosphate metabolism, have been found to account, at least partly, for the excessively high cardiovascular morbidity and mortality in these patients [8]. Non-traditional risk factors become more important along the progression of renal failure. Importantly, CKD patients are likely to die of CVD before even reaching end stage renal disease (ESRD) [9]. Prevalent CV phenotypes in CKD include atherosclerosis, cardiac arrythmia and vascular calcification (VC) [10]. VC affects up to $60 \%$ of CKD patients and is even more prevalent in dialysis patients [11]. Furthermore, it has been independently associated with CV morbidity and mortality [11,12]. Impaired renal function leads to retention of numerous compounds (referred to as uremic retention molecules, URMs). Information on the impact of URMs on vascular (patho) biology, in general, is limited and fragmentary, and pathophysiological mechanisms remain largely obscure. In this review, we present a state of the art on the effects of uremic retention molecules on vascular smooth muscle cells (VSMC) with relevance for early vascular ageing (EVA) and VC related CVD. Early vascular ageing-a modifiable, not passive entropic process [13]-is an evolving construct that has been growing around accumulating evidence surrounding arterial stiffness as an intermediate end-point and independent predictor of CVD. CKD-associated EVA is characterized by a loss of plasticity and/or resilience to adaptions against the changing internal uremic environment, which results in a marked discrepancy between chronological and biological vascular age [14]. In depth analysis of translational cohort studies investigating extreme EVA, such as CKD, provides valuable insights in factors that drive vascular ageing, and which may be also present in the older general population but take considerable longer time to evolve.

\section{Vascular Calcification}

VC as consequence of EVA can occur at two distinct sites: in the intimal layer of vessels where it is associated with atherosclerosis and in the medial layer, where it is also referred to as Mönckeberg sclerosis. Medial calcification is linked to non-traditional risk factors and is a common feature in CKD, which often co-exist with intimal calcification $[15,16]$. Arterial calcium depositions have long been perceived as a passive process strongly associated with aging. This common opinion shifted as more recent research showed that VC is an actively regulated process involving a delicate balance between calcification activators and inhibitors, present both in the vessel wall and in the circulation [17]. The medial layer of larger arteries is predominantly composed of VSMC, a differentiated cell type expressing a set of characteristic proteins (e.g., smooth muscle myosin heavy chain, sm22 alpha and myocardin). Contractile VSMC are significantly involved in maintaining vascular tone and structural integrity of the vessel wall. However, VSMC are not terminally differentiated and retain a high degree of phenotypic plasticity. Mechanical and/or chemical stress promote a phenotypic transition of the VSMC into a synthetic state, characterized by an increased ability to synthesize extracellular matrix components and accompanied by increased capacity for migration and proliferation [18]. Dedifferentiated VSMC have a variety of cell-fates, including macrophage-like, myofibroblast-like and osteo-chondrogenic-like phenotype [19]. Osteo-chondrogenic VSMC are characterized by a loss of contractility marker and an increase in osteo-chondrogenic marker proteins (e.g., Runt-related transcription factor 2 [Runx2], alkaline phosphatase [ALP], SRY-Box Transcription Factor 9 [Sox9], bone morphogenetic protein 2 [BMP2]). It has been reported that VSMC calcification is related to cellular senescence. Ref. [14] Furthermore the change in phenotype is accompanied by an increase in release of calcifying extracellular vesicles, elastin degradation and creation of a calcification-prone matrix [20]. Osteo-chondrogenic VSMC support the growth of hydroxyapatite (HA) crystals in the vessel wall, which defines calcification. Osteo-chondrogenesis and VC are driven by stressors including high phosphate, high calcium, oxidative stress, inflammation, senescence, apoptosis and alkalinization [21,22], all (except alkalinization) common manifestations of uraemia. Thus, non-surprisingly, uremic serum accelerates VC in VSMC in vitro [23-25]. 


\section{Uremic Toxins and Their Effects on VSMC}

Uraemia (in Greek) literally means "urine in the blood". A key future of the uraemic syndrome is the accumulation of URMs. URMs comprise an extremely heterogenous group of molecules of different origins, molecular weight (MW), biological functions and physico-chemical properties [26,27]. Their classification into middle molecules (MM, MW > $500 \mathrm{Da})$, protein bound uremic retention molecules (PBURM) and low molecular weight solutes (LMWS, MW $<500 \mathrm{Da}$ ) has been widely accepted [28].

The present literature review aims to update current evidence of the role of URMs in VC [29]. A total of 151 URMs were included of which 46 were classified as MM, 32 as PBURM, and 73 as LMWS (Table 1). For only $17.2 \%$ of these URMs, the impact on VC has been investigated in an in vitro setting. In vivo and clinical data are even more limited (Figure 1). Thus, huge research gaps persist on whether and how URMs influence VC development or modify its progression

Table 1. Described URM where selected to be part of this review on basis of the database maintained by the European Uremic Toxin work group, complemented by two further publications. Table 1 summarizes the basic information of the included URM, showing the number of molecules per group (\#) and the respective percentage from all molecules (\%), as well as the characteristic size range and a typical example molecule.

\begin{tabular}{ccccc}
\hline Middle molecules & $46(30,5)$ & $\#(\%)$ & MW $>500 \mathrm{Da}$ & e.g., TNF \\
Protein bound & $32(21,2$ & $\#(\%)$ & - & e.g., Indoxyl sulfate \\
Water soluble & $73(48,3)$ & $\#(\%)$ & $\mathrm{MW}<500 \mathrm{Da}$ & e.g., Urea \\
Total & $151(100)$ & $\#(\%)$ & & \\
\hline
\end{tabular}

MM are predominantly proteins and peptides generated endogenously as a response to uraemia, such as cytokines and peptide hormones. Dialysis has limited efficacy in controlling MM, partly related to size restriction of the pores of dialyzers [26]. Of the $46 \mathrm{MM}$ included in this review, 9 (19.6\%) have been investigated with respect to effects on VC. Of these 46, all belong to the subgroups of inflammatory cytokines and peptide hormones. A summary of the effects of MM on VSMC calcification is given in Table 2 (Supplementary Table S1).

PBURM are a heterogenous group of solutes, characterized by reversible protein binding capacity. PBURM are considered a major threat to ESRD patients, partly because of their limited removal by conventional dialysis [30]. Of the 32 PBURM included in this review 5 (15.6) have been investigated with respect to effects on VC. A summary of their effects on VSMC calcification is given in Table 3 (Supplementary Table S2).

The group of LMWS comprises compounds with molecular weight $<500 \mathrm{kDa}$ and minimal protein binding. Reduction rates of LMWS during dialysis are overall high, but show substantial variability [26]. Twelve out of the 73 LMWS (16.4\%) have been investigated with respect to potential effects on VC (Figure 1, Table 4 and Supplementary Table S3). LMWS have been neglected for a long time but interest in this class of URMS has increased in recent years, as it has become clear that they considerably affect patient well-being and may contribute substantially to vascular pathobiology [26]. Thus, LMWS might hold significant potential as therapeutic target, also considering that it is the largest and most understudied class with respect to VC. URM of the class MM as well as PBURM are approximately 2.5 times more often investigated compared to LMWS. That might partially be due to the fact that MM contain many non-uraemia specific molecules, e.g., inflammatory cytokines and peptide hormones also relevant for many other diseases [28]. This leads to a seemingly higher level of clinical evidence for these molecules, while the level of evidence generally remains low. 
Table 2. Repository of studies investigating MM towards their effect on VC, as well as their effects on VC related processes in VSMC.

\begin{tabular}{|c|c|c|c|c|c|c|c|c|c|c|c|}
\hline & $\begin{array}{l}\text { Calcification } \\
\text {-In Vitro }\end{array}$ & $\begin{array}{l}\text { Calcification } \\
\text {-In Vivo }\end{array}$ & $\begin{array}{c}\text { Calcification } \\
\text {-Clinical Studies }\end{array}$ & Osteogenesis & $\begin{array}{l}\text { Oxidative } \\
\text { Stress }\end{array}$ & Inflammation & Apoptosis & Senescence & Proliferation & Migration & Atherosclerosis \\
\hline APN & $\begin{array}{l}\downarrow[31-33] \\
-[34]\end{array}$ & $\downarrow[35,36]$ & $\begin{array}{c}\uparrow[37-39] \\
\downarrow[40,41] \\
-[42-44]\end{array}$ & $\downarrow[31,36]$ & & $\downarrow[45]$ & $\downarrow[33,35]$ & & $\downarrow[46,47]$ & $\downarrow[48,49]$ & $\downarrow[49,50]$ \\
\hline $\mathrm{ADM}$ & $\downarrow[51,52]$ & $\downarrow[51,53]$ & & $\downarrow[53]$ & $\downarrow[54,55]$ & & & & $\begin{array}{l}\uparrow[56,57] \\
\downarrow[58,59]\end{array}$ & $\downarrow[60,61]$ & \\
\hline ET & $\uparrow[62]$ & $\uparrow[62-64]$ & $\uparrow[65-67]$ & & $\uparrow[68-70]$ & $\uparrow[69,71]$ & $\begin{array}{l}\uparrow[72] \\
\downarrow[73]\end{array}$ & & $\uparrow[74,75]$ & $\uparrow[76,77]$ & $\uparrow[78,79]$ \\
\hline IL-8 & $\uparrow[80]$ & & $\begin{array}{l}\uparrow[81] \\
-[82]\end{array}$ & & & $\downarrow[83]$ & & & $\uparrow[84,85]$ & $\uparrow[84,85]$ & \\
\hline IL-18 & $\uparrow[86,87]$ & & $\uparrow[88-90]$ & $\uparrow[86,87]$ & $\uparrow[91]$ & $\uparrow[92,93]$ & & & $\uparrow[94,95]$ & $\uparrow[96,97]$ & $\uparrow[98,99]$ \\
\hline IL-1 $\beta$ & $\begin{array}{c}\uparrow[100,102] \\
\sim[103]\end{array}$ & $\uparrow[101,104,105]$ & $-[101,102,106]$ & $\begin{array}{c}\uparrow[100,102] \\
\sim[107]\end{array}$ & $-[108]$ & $\uparrow[109,110]$ & $\uparrow[111,112]$ & $\uparrow[102]$ & $\uparrow[113,114]$ & $\uparrow[114,115]$ & $\uparrow[101,116]$ \\
\hline IL-6 & $\uparrow[117-122]$ & $\uparrow[118,119,123]$ & $\uparrow[41,106,124-129]$ & $\uparrow[118,120,122,130]$ & $\uparrow[131]$ & $\uparrow \downarrow[130]$ & $\uparrow[132,133]$ & $\uparrow[121]$ & $\uparrow[134,135]$ & $\uparrow[135,136]$ & $\uparrow[118,120]$ \\
\hline PTH & $\uparrow[137,138]$ & $\begin{array}{c}\uparrow[137,139,140] \\
\downarrow[141,142]\end{array}$ & $\begin{array}{c}\uparrow[129,143] \\
-[144]\end{array}$ & $\uparrow[137]$ & $\downarrow[141]$ & & & & $-[145]$ & & \\
\hline $\mathrm{TNF}$ & $\uparrow[107,146-152]$ & $\uparrow[149]$ & $\begin{array}{l}\uparrow[126,129] \\
-[44,128]\end{array}$ & $\uparrow[107,146,149,153]$ & $\uparrow[154,155]$ & $\uparrow[156,157]$ & $\uparrow[158,159]$ & & $\uparrow[160,161]$ & $\uparrow[160,162]$ & $\uparrow[163,164]$ \\
\hline
\end{tabular}

$\uparrow=$ increase, $\downarrow=$ decrease, $-=$ tested, but no effect, $\sim=$ unclear effect, Abbreviations: Adrenomedullin $=$ ADM, Endothelin $=$ ET, Interleukin $=$ IL, Parathyroid hormone $=$ PTH, Tumor necrosis factor alpha $=$ TNF- $\alpha$, Adiponectin $=$ APN.

Table 3. Repository of studies investigating PBURM towards their effect on VC, as well as their effects on VC related processes in VSMC.

\begin{tabular}{|c|c|c|c|c|c|c|c|c|c|c|c|}
\hline & $\begin{array}{l}\text { Calcification } \\
\text {-In Vitro }\end{array}$ & $\begin{array}{c}\text { Calcification } \\
\text {-In Vivo } \\
\end{array}$ & $\begin{array}{c}\text { Calcification } \\
\text {-Clinical Studies }\end{array}$ & Osteogenesis & $\begin{array}{c}\text { Oxidative } \\
\text { Stress }\end{array}$ & Inflammation & Apoptosis & Senescence & Proliferation & Migration & Atherosclerosis \\
\hline Hcy & $\uparrow[165-169]$ & $\uparrow[165,168-171]$ & $\begin{array}{c}\uparrow[170,172-177] \\
-[106,128,178-181]\end{array}$ & $\uparrow[165,166,168,169]$ & $\uparrow[182,183]$ & $\uparrow[184,185]$ & $\begin{array}{c}\uparrow[186,187] \\
-[188]\end{array}$ & & $\uparrow[189,190]$ & $\uparrow[191,192]$ & $\uparrow[193,194]$ \\
\hline IS & $\uparrow[29,80,195-197]$ & $\uparrow[195,197,198]$ & $\begin{array}{c}\uparrow[199,200] \\
-[201]\end{array}$ & $\uparrow[80,196,197,202]$ & $\uparrow[202,203]$ & $\uparrow[204,205]$ & $\uparrow[29]$ & $\uparrow[29]$ & $\uparrow[206,207]$ & $\uparrow[208,209]$ & $\uparrow[29,210]$ \\
\hline Leptin & $\uparrow[211-213]$ & $\uparrow[211,214,215]$ & $\begin{array}{c}\uparrow[40,216-219] \\
-[41,44]\end{array}$ & $\uparrow[211,213,214,220]$ & $\uparrow[221,222]$ & $\uparrow[221,223]$ & $\begin{array}{l}\uparrow[222] \\
\downarrow[224]\end{array}$ & & $\begin{array}{c}\uparrow[223,225] \\
\downarrow[226]\end{array}$ & $\uparrow[227,228]$ & $\uparrow[212,229]$ \\
\hline CML & $\uparrow[230]$ & $\uparrow[230]$ & $\uparrow[231]$ & $\uparrow[230]$ & & $\uparrow[232]$ & $\downarrow[233]$ & & $\uparrow[233]$ & & $\uparrow[230]$ \\
\hline $\mathrm{pCS}$ & & $\uparrow[198]$ & $\uparrow[234]$ & $\uparrow[235]$ & $\uparrow[235,236]$ & $\uparrow[198,235]$ & & & $\uparrow[237]$ & $\uparrow[237]$ & $\uparrow[237,238]$ \\
\hline SM & $\downarrow[239]$ & & & & $\uparrow[240]$ & & $\uparrow[241,242]$ & & $\begin{array}{c}\uparrow[243,244] \\
\downarrow[245] \\
\end{array}$ & & \\
\hline
\end{tabular}

$\uparrow=$ increase $\downarrow \downarrow$ decrease,$-=$ tested, but no effect. Abbreviations: Homocystein $=$ Hcy, Indoxyl sulfate $=$ IS, N(6)-Carboxymethyllysine $=$ CML, $\mathrm{p}$ cresyl sulfate $=$ pCS, Spermine $=$ SM. 
Table 4. Repository of studies investigating LMWS towards their effect on VC, as well as their effects on VC related processes in VSMC.

\begin{tabular}{|c|c|c|c|c|c|c|c|c|c|c|c|}
\hline & $\begin{array}{l}\text { Calcification } \\
\text {-In Vitro }\end{array}$ & $\begin{array}{l}\text { Calcification } \\
\text {-In Vivo }\end{array}$ & $\begin{array}{c}\text { Calcification } \\
\text {-Clinical Studies }\end{array}$ & Osteogenesis & $\begin{array}{c}\text { Oxidative } \\
\text { Stress }\end{array}$ & Inflammation & Apoptosis & Senescence & Proliferation & Migration & Atherosclerosis \\
\hline ADMA & $\downarrow[246]$ & & $\begin{array}{c}\uparrow[247-251] \\
-[252]\end{array}$ & & $\uparrow[253]$ & $\uparrow[254]$ & $\uparrow[253]$ & & $\begin{array}{c}\uparrow[254,255] \\
-[246]\end{array}$ & $\downarrow[256,257]$ & \\
\hline G & $-[246]$ & & & & & & & & $-[246]$ & & \\
\hline GAA & $-[246]$ & & & & & & & & $-[246]$ & & \\
\hline GSA & $\downarrow[246]$ & & & & & & & & $-[246]$ & & \\
\hline MG & $-[246]$ & & & & & & & & $-[246]$ & & \\
\hline MMA & $\downarrow[258]$ & & & $\downarrow[258]$ & & & $\uparrow[259]$ & & & & \\
\hline NA & $\uparrow[260]$ & $\uparrow[260]$ & & $\uparrow[260]$ & & & & & $\uparrow[261,262]$ & $\uparrow[263,264]$ & \\
\hline SDMA & $\downarrow[246]$ & & & & & & & & $-[246]$ & & \\
\hline TMAO & $\uparrow[265]$ & $\uparrow[265]$ & $-[266]$ & $\uparrow[265]$ & & $\uparrow[265,267]$ & & & & & $\uparrow[267]$ \\
\hline UA & $\uparrow[268,269]$ & $\uparrow[269]$ & $\begin{array}{c}\uparrow[270-273] \\
-[274]\end{array}$ & $\uparrow[268,269]$ & $\uparrow[275-278]$ & $\uparrow[276,279]$ & & & $\uparrow[280,281]$ & $\uparrow[282]$ & $\uparrow[276]$ \\
\hline $\begin{array}{l}\text { GPA } \\
\text { GBA }\end{array}$ & $\begin{array}{l}-[246] \\
-[246]\end{array}$ & & & & & & & & $\begin{array}{l}-[246] \\
-[246]\end{array}$ & & \\
\hline
\end{tabular}

$\uparrow=$ increase,$\downarrow=$ decrease,$-=$ tested, but no effect. Abbrevations: $\gamma$-guanidinobutyric Acid = GBA, $\beta$-Guanidinopropionic Acid $=$ GPA, Uric acid $=$ UA, Trimethylamine-N-oxide $=$ TMAO, Symmetric Dimethylarginine = SDMA, Asymmetric Dimethylarginine = ADMA, Noradrenalin = NA, Monomethylamine = MMA, Methylguanidine = MG, Guanidino succinic acid = GSA, Guanidino acetic acid = GAA, Guanidine = G 


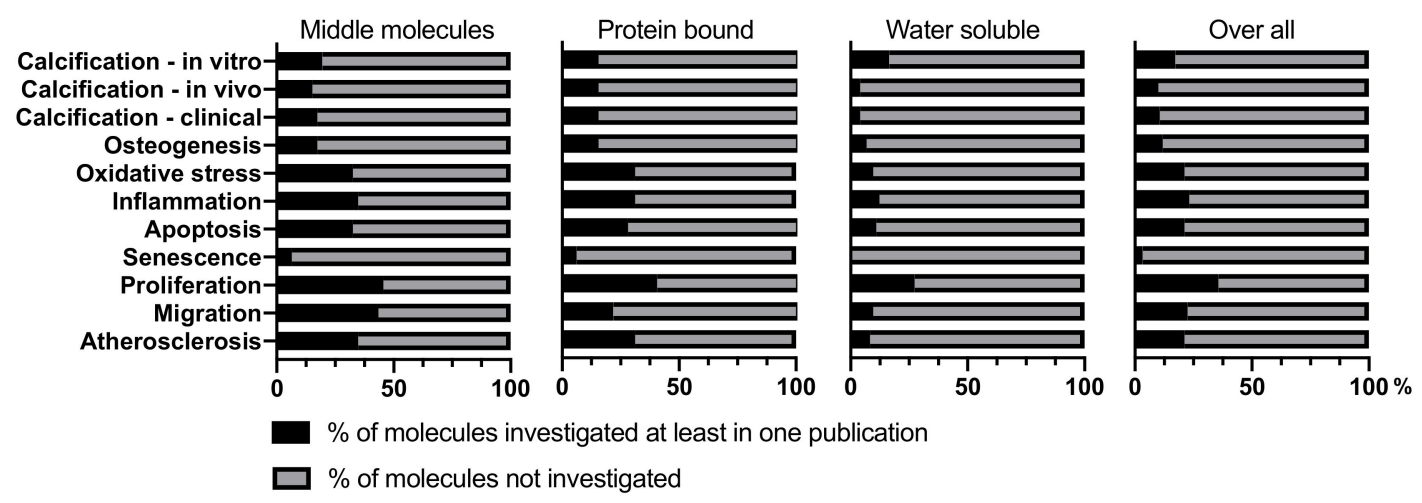

Figure 1. Literature was screened for effects of uremic retention molecules on vascular smooth muscle cells, with relevance for vascular calcification. Relevant review terms have been defined as the three levels of calcification research-in vitro, in vivo and clinical, and were completed by pertinent phrases. The extent to which molecules of each group have (black bar) or have not (grey bar) been investigated with respect to a given topic, displayed as \% per group, is presented.

Overall, information on the impact of uremic toxins on the process of vascular calcification, in all its aspects, is fragmentary (Figure 1) and by large incomplete; e.g., for none of the URM, information was available on the impact of either release or composition of extracellular vesicles released by VSMC, which recently gained attention as modifiers of the VC process [283].

\section{Challenges in Uremic Toxin-VC Research}

Experimental heterogeneity hampers comparison of data. Primary human, bovine, mouse and rat VSMCs as well as cell lines have been used by different investigators. Interspecies differences may account at least partly for inconsistent findings. VSMC derived from different topographic locations of the vascular tree may differ in their physiology and pathophysiology [284]. In addition, experimental conditions diverge substantially and may introduce substantial heterogeneity with major impact on the outcome. As an example, URM are tested as standalone or in combination with either $\mathrm{Ca}^{2+}$ or Pi. Also, for $\mathrm{Ca}^{2+}$ or $\mathrm{Pi}$, concentration, donor (e.g., $\beta$-Glycerophosphate vs. $\mathrm{Na}_{2} \mathrm{HPO}_{4}$ ), exposure time and the use of foetal bovine serum (FBS) are subject to differences. A proposal for standardization has recently been put forward, however consensus has not been reached yet [285]. Additionally, the concentration of the URMs to which the VSMC are exposed matters and should ideally reflect/mimic the clinical situation. The European uremic toxin work group (EUTox) published recommendations on handling and use of URM which serves as guideline. In this respect, especially the protein bound uremic toxins deserve attention since guidelines recommend to add human serum albumin at the average uremic concentration of $35 \mathrm{~g} / \mathrm{L}$ to any test system not containing protein [286]. This recommendation assumes that only the free fraction of uremic toxins exerts an effect. However, none of the publications included in this review was performed in a protein free system, but used FBS in varying concentrations containing an untested concentration of protein. Using FBS free conditions in a calcification experiment remains challenging but might be desirable to overcome this limitation. FBS also contains unknown substances and factors known to influence calcification, like Fetuin-A [287,288]. In lieu of FBS free conditions, reporting of medium protein concentrations could be an alternative and to assess the effect of the free URM fraction and foster reproducibility.

As discussed earlier, URM may affect the process of calcification also by indirectly targeting VSMC. For instance, urea and thiocyanate serve as substrates for carbamylation of LDL and proteins [289,290], an event that has recently been identified as a key driver of VC in CKD [291]. Furthermore, the multifaceted effects of especially cytokines and hormones might lead to effects relevant for VC which cannot be assessed by looking at VSMC alone, e.g., PTH (Table 2). The pleiotropic endocrine nature of hormones may not allow a credible conclusion by examining VSMC alone. Therefore, even 
though a direct impact of certain URM on VSMC calcification has not been established, it might not render them obsolete. Reviewing the indirect effects of URM on VSMC calcification was beyond the scope of this review. However, the above underlines the need for more research in advanced models, comprised of in vitro co-cultures and in vivo experiments.

Literature also inheres a considerable inconsistency in effects of URM on VC between experimental and clinical studies. Biomarker assays only reflect a snapshot in time and neglect the slow progressive nature of CKD [292] and its metabolic complications, including VC. Furthermore, the relevance of systemic URM levels for the vascular microenvironment remains a concern.

The conflicting results obtained in clinical and in vitro studies preclude strong conclusions. Furthermore, consistency of the findings is often limited. Indeed, 15 out of 26 URM have been tested only once in vitro and thus lack independent confirmation. Additionally, we found inconsistencies between clinical studies investigating the same URM. Both case-mix and variable residual confounding may account for these inconsistencies. Furthermore, clinical studies can only indicate correlation and not prove causation. In this context also correction for confounding factors might be challenging giving the multifaceted nature of CKD and the huge body of yet explored influences of the URM. Moreover, the Bradford Hill criteria [293] have not been fulfilled by any of the solutes, which underscores that current evidence is insufficient to establish a reliable cause-effect relationship, between any single URM and VC. Thus, future recommendations should be based on in vitro and in vivo preclinical and clinical research to provide impactful decisions for the advancement of quality of life for CRS patients.

Uremic serum and Pi induces phenotypic modulation and calcification of VSMC differently, thereby underscoring the importance of the uremic toxins as contributors to VC [23]. However the complexity of the composition of uremic serum and the fact that 26 different molecules have been linked to VC already, with many more having yet unclear impact (Figure 1), make it unlikely that one single substance can be identified as the "holy grail". It is more probable that the effects leading to increased VC are attributable to an orchestra of factors questioning the effects found by testing individual molecules as being representative for the situation in situ (uremic toxin storm). It is more likely that different toxins have synergistic effects, however, might also partially antagonize each other or prime the vasculature for other toxins to be effective, without exerting an effect on its own. However, these possible ties between uremic toxins remain yet unstudied.

These findings call for a more standardized and systematic approach in order to ensure relevance of results for the therapeutic setting and to facilitate comparability between studies.

\section{Treatment Strategies}

Although there is currently no approved therapy to stop, attenuate or regress VC there are several appealing approaches [294,295]. These may be categorized as: (1) direct pharmacological inhibition of hydroxyapatite (HA) growth, (2) increasing level or activity of anti-calcifying factors, (3) reducing pro-calcifying factors. Multiple compounds for direct pharmacological inhibition of HA crystal growth are currently in development e.g., sodium thiosulfate, myo-inositol hexaphosphate or bisphosphonates. SNF472, a myo-inositol hexaphosphate formulation, was recently reported to significantly reduce progression of VC in HD-patients in a phase $2 b$ trial [296]. Supplementation with vitamin $\mathrm{K}$ is under investigation to increase activity of anti-calcifying vitamin $\mathrm{K}$ dependent proteins. Vitamin $\mathrm{K}$ is an unequivocal cofactor for the gamma-glutamylcarboxylation of protein bound glutamate residues. This carboxylation is pivotal to activate the endogenous VC inhibitor matrix Gla-protein (MGP) [297]. Several clinical trials are currently underway to examine the potential of vitamin K supplementation to hold or reduce VC [294]. Additionally, also certain URM can be protective against VC (Tables 2-4), yet this has not been studied in detail. The newly emerging field of senolytics as medication might also be a promising new treatment strategy for reducing VC [298]. Renal replacement therapy as a strategy to reduce pro-calcifying factors has its limitations; e.g., the removal of PBURM by conventional haemodialysis is poor. As many vasotoxic compounds originate from gut microbial metabolism, the large intestine is increasingly recognized as an promising target of therapy. 


\section{Future Perspectives}

The composition of the uremic serum differs vastly among CDK patients. Thus, although CKD patients suffer from $\mathrm{VC}$, the underlying cause for $\mathrm{VC}$ development may differ. In order to progress towards more personalized CKD and CRS treatment strategies a better understanding of the individual uremic toxin profile is needed. This might pave the way for the early identification of patients with a higher risk for VC development and accelerated progression. Thus far, comprehensive URM profiles of individual patients are not available and information stem from measurements of a limited number of URM. Moreover, since the list of URM is constantly updated, it is difficult to define all molecules relevant in the context of VC [26]. A comprehensive understanding of the effect of individual URM is needed to identify and reduce the burden of pro-calcifying factors caused by the entire pool of URM. Since testing each URM in depth is nearly impossible, evaluating URM by classifying and clustering them to determine potential relevance will pave the way for targeted treatment strategies. We strongly put forward a structured, systematic and unbiased approach in assessing effects of URM on VSMC being most effective in revealing detrimental or beneficial effects on VC (Figure 2). Clustering of known URM based on their chemical similarity combined with proven effects might be an attractive possibility. As such, systematic screening by testing representative URM of each cluster will provide knowledge on similar URM in that cluster. Moreover, it could be worthwhile identifying common signaling pathways activated by multiple URM. This would open new avenues for counteracting the effects of URM, with very different origins and challenges for their removal. Alternatively, segregation of the overwhelming uremic toxin "storm" into manageable units might present an idea worth exploring. Such units may include the CKD-mineral bone disorder or rebalancing the inflammatory profile. A newly emerging link between intestinal microbiota and VC could also present an accessible unit [299]. A considerable fraction of the uremic toxins have been found to be gut derived [26] some of which have already been linked to VC including TMAO, IS and pCS (Tables 3 and 4). TMAO has further been found to be indicative of intestinal dysbiosis [300], further supporting the idea of a intestine-vascular axis in CRS pathology. Therefore, a more detailed understanding of the origin of each URM might identify novel intervention sites. Moreover, senescence as feature of EVA, which has been linked to VC, should receive more attention during the design of future experiments. Extracellular vesicles are recognized as contributor to VC development, and increased vesicle secretion is associated with VSMC phenotypic switching [301,302]. Furthermore, circulating extracellular vesicles isolated from CDK patients increase VSMC osteogenic-phenotypic switching and VC [303]. Therefore, we strongly advocate for acknowledging extracellular vesicle release as process indirectly linked VC, which should receive attention also in CRS centred research. 


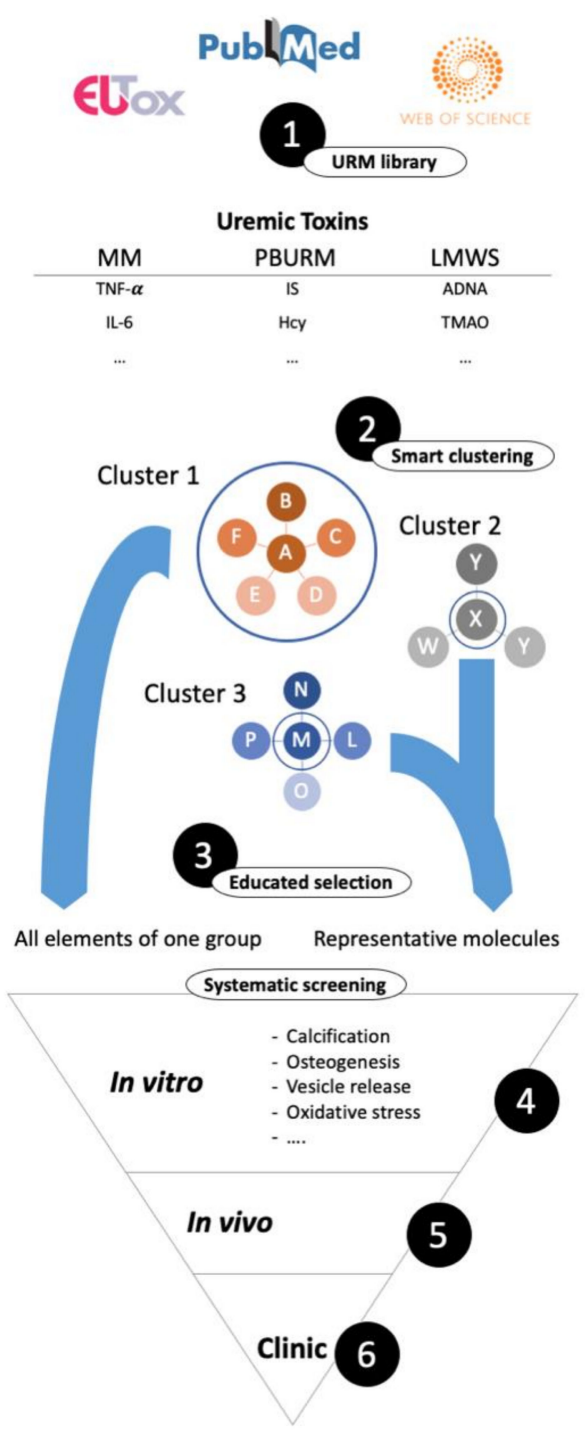

Figure 2. Outline of a systematic screening approach for uremic retention molecules (URM). 1. URM need to be collected and organized in a library, possibly starting with the European Uremic Toxin Work Group's database, extended by recent discoveries. 2. URM need to be logically sorted into smaller, accessible groups. Clustering strategies could be based on chemical similarity, origin, or others. 3. A selection for actual testing needs to be applied which could be by, educated guessing based on known effects, testing the representative molecule from each cluster to identify relevant subgroups or by testing cluster wise. 4 . Selected molecules are tested systematically in on one or more cell types for relevant effects like calcification, inflammation, apoptosis, etc. ... in vitro, 5. If successful in vivo and 6 . On a clinical level.

\section{Summary}

In this review, we included literature investigating URM and VSMC calcification in vitro, in vivo and on a clinical level. A clear definition of URM being detrimental, harmless or beneficial with respect to vascular calcification is currently lacking. Furthermore, we identify many gaps in URM research related to VSMC. A large fraction of URM has not been investigated with respect to their effects on VSMC calcification. However, some are linked to processes indirectly associated with VSMC calcification, such as ROS and inflammation. We also include potential novel avenues of VSMC driven calcification, such as extracellular vesicles, senescence and the influence of the microbiome. Effects of URM are often reported once in publications, and experimental conditions often lack an adequate 
degree of standardization and are not designed in relation to CRS. The composition of uremic serum is divers and may differ vastly between patients. Moreover, the influence of many uremic retention molecules on VSMC and VC, remain largely obscure and the underlying effects poorly understood. Better understanding of the effects of URM on the vasculature could be the first step towards reducing VC and a personalized CKD treatment strategy. This underscores the need for deep patient serum profiling to understand the underlying cause and consequence relationship between URM and clinical manifestations. In conclusion, our narrative overview puts forward the hypothesis to test effects of URM on VSMC in relation to VC more systematically and advocates for more CRS centred research.

\section{Search Strategy}

The European uremic toxin work group has created an extensive database [304] containing many relevant uremic retention molecules, which served as the basis for the literature research and has been supplemented by compounds from two further publications $[28,305]$. The search was performed in the Medline library accessed via Pubmed using the search term "-molecule- AND (smooth muscle cell OR vascular smooth muscle cell OR VSMC OR SMC) AND (calcif* OR inflam* OR oxidative stress OR vesicle OR proliferation OR migration OR apoptosis OR necrosis OR senescence OR osteo* OR chondro* OR monocyte OR macrophage OR athero*)." If no article could be found with this strategy, at least one alternative name for this molecule has been tried in the same search term. If more than 160 articles have been found for a single molecule, the articles were sorted by "best match", and the first 160 hits, as well as reviews from the past 10 years were included. Furthermore if publications concerning in vitro and/or in vivo results on calcification could be found, the search was extended for only these molecules to identify clinical cohort studies that relate the respective molecule to vascular calcification in a clinical setting by using the search term "-molecule- AND calcification AND cohort" as well as "-molecule- AND calcification".

Supplementary Materials: The following are available online at http:/www.mdpi.com/2072-6651/12/10/624/s1, Table S1: Full table of the included MM and their influence on calcification, as well as their effects on VC related processes in VSMC. Table S2: Full table of the included PURM and their influence on calcification, as well as their effects on VC related processes in VSMC. Table S3: Full table of the included LMWS and their influence on calcification, as well as their effects on VC related processes in VSMC.

Author Contributions: Conceptualization, N.R. and L.S.; methodology, N.R.; software, N.R.; resources, N.R.; data curation, N.R.; writing-original draft preparation, N.R.; writing-review and editing, P.S., P.E., L.S.; visualization, N.R.; supervision, L.S.; funding acquisition, L.S. All authors have read and agreed to the published version of the manuscript.

Funding: This project has received funding from the European Union's Horizon 2020 research and innovation programme under the Marie Skłodowska-Curie grant agreement No. 764474.

Conflicts of Interest: The authors declare no conflict of interest.

$\begin{array}{ll}\text { Abbreviations } \\ \text { ADM } & \text { Adrenomedullin } \\ \text { ADMA } & \text { Asymmetric Dimethylarginine } \\ \text { ALP } & \text { alkaline phosphatase } \\ \text { APN } & \text { Adiponectin } \\ \text { BMP2 } & \text { bone morphogenetic protein } 2 \\ \text { CAC } & \text { coronary artery calcification } \\ \text { CKD } & \text { Chronic kidney disease } \\ \text { CML } & \text { N(6)-Carboxymethyllysine } \\ \text { CRS } & \text { cardiorenal syndrome } \\ \text { CV } & \text { cardiovascular } \\ \text { CVD } & \text { cardiovascular disease } \\ \text { ESRD } & \text { End stage renal disease } \\ \text { ET } & \text { Endothelin }\end{array}$




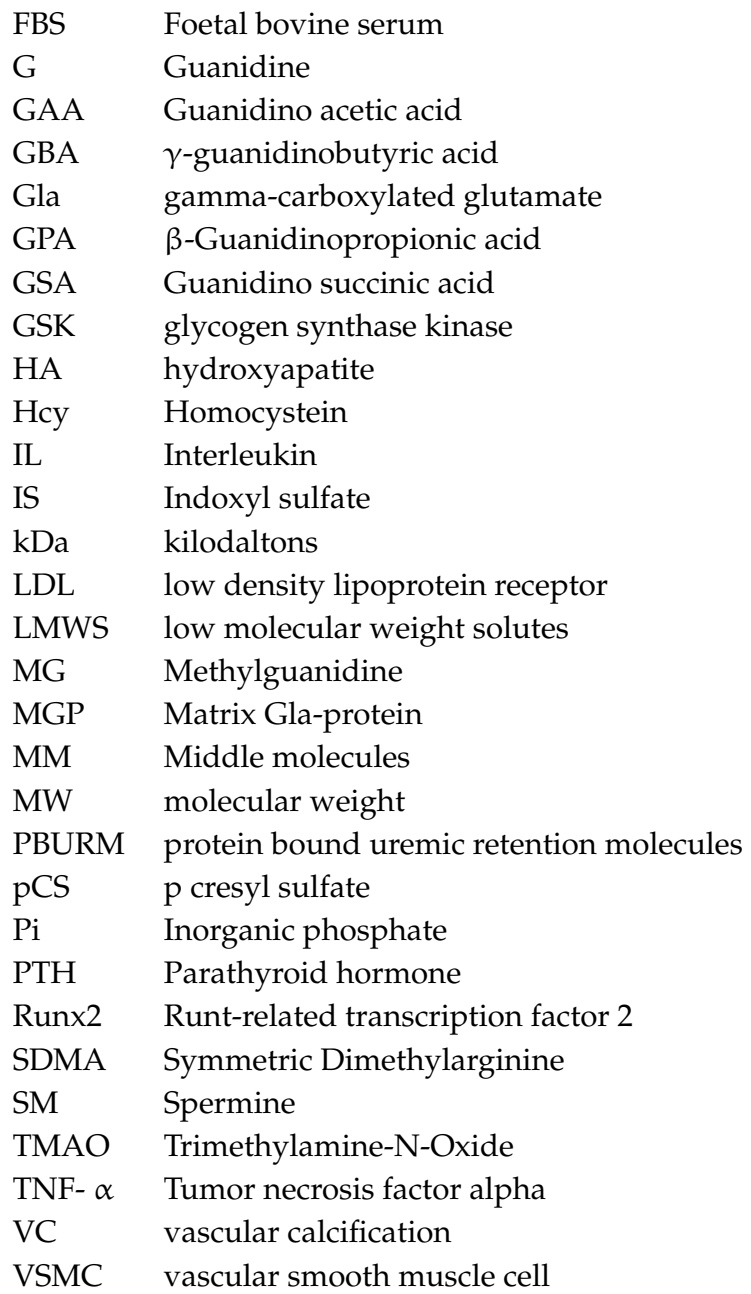

\section{References}

1. Kassebaum, N.J.; Arora, M.; Barber, R.M.; Bhutta, Z.A.; Brown, J.; Carter, A.; Casey, D.C.; Charlson, F.J.; Coates, M.M.; Coggeshall, M.; et al. Global, regional, and national disability-adjusted life-years (DALYs) for 315 diseases and injuries and healthy life expectancy (HALE), 1990-2015: A systematic analysis for the Global Burden of Disease Study 2015. Lancet 2016, 388, 1603-1658. [CrossRef]

2. Hill, N.R.; Fatoba, S.T.; Oke, J.L.; Hirst, J.A.; O'Callaghan, C.A.; Lasserson, D.S.; Hobbs, F.D.R. Global Prevalence of Chronic Kidney Disease-A Systematic Review and Meta-Analysis. PLoS ONE 2016, 11, e0158765. [CrossRef] [PubMed]

3. Khan, S.; Amedia, C.A. Economic burden of chronic kidney disease. J. Eval. Clin. Pract. 2008, 14, $422-434$. [CrossRef] [PubMed]

4. Khan, S.S.; Kazmi, W.H.; Abichandani, R.; Tighiouart, H.; Pereira, B.J.G.; Kausz, A.T. Health care utilization among patients with chronic kidney disease. Kidney Int. 2002, 62, 229-236. [CrossRef] [PubMed]

5. Unger, E.D.; Dubin, R.F.; Deo, R.; Daruwalla, V.; Friedman, J.L.; Medina, C.; Beussink, L.; Freed, B.H.; Shah, S.J. Association of chronic kidney disease with abnormal cardiac mechanics and adverse outcomes in patients with heart failure and preserved ejection fraction. Eur. J. Heart Fail. 2016, 18, 103-112. [CrossRef] [PubMed]

6. De Jager, D.J.; Grootendorst, D.C.; Jager, K.J.; Van Dijk, P.C.; Tomas, L.M.J.; Ansell, D.; Collart, F.; Finne, P.; Heaf, J.G.; Meester, J.D.; et al. Cardiovascular and Noncardiovascular Mortality Among Patients Starting Dialysis. JAMA 2009, 302, 1782-1789. [CrossRef] [PubMed]

7. Rangaswami, J.; Bhalla, V.; Blair, J.E.A.; Chang, T.I.; Costa, S.; Lentine, K.L.; Lerma, E.V.; Mezue, K.; Molitch, M.; Mullens, W.; et al. Cardiorenal Syndrome: Classification, Pathophysiology, Diagnosis, and Treatment Strategies: A Scientific Statement from the American Heart Association. Circulation 2019, 139, e840-e878. [CrossRef] [PubMed] 
8. Alani, H. Cardiovascular co-morbidity in chronic kidney disease: Current knowledge and future research needs. World J. Nephrol. 2014, 3, 156. [CrossRef]

9. Vlagopoulos, P.T.; Sarnak, M.J. Traditional and Nontraditional Cardiovascular Risk Factors in Chronic Kidney Disease. Med. Clin. N. Am. 2005, 89, 587-611. [CrossRef]

10. Di Lullo, L.; House, A.; Gorini, A.; Santoboni, A.; Russo, D.; Ronco, C. Chronic kidney disease and cardiovascular complications. Heart Fail. Rev. 2015, 20, 259-272. [CrossRef]

11. Wang, X.-R.; Zhang, J.-J.; Xu, X.-X.; Wu, Y.-G. Prevalence of coronary artery calcification and its association with mortality, cardiovascular events in patients with chronic kidney disease: A systematic review and meta-analysis. Renal Fail. 2019, 41, 244-256. [CrossRef] [PubMed]

12. Rennenberg, R.J.M.W.; Kessels, A.G.H.; Schurgers, L.J.; Van Engelshoven, J.M.A.; De Leeuw, P.W.; Kroon, A.A. Vascular calcifications as a marker of increased cardiovascular risk: A meta-analysis. Vasc. Health Risk Manag. 2009, 5, 185-197. [CrossRef] [PubMed]

13. Cunha, P.G.; Boutouyrie, P.; Nilsson, P.M.; Laurent, S. Early Vascular Ageing (EVA): Definitions and Clinical Applicability. Curr. Hypertens. Rev. 2017, 13, 8-15. [CrossRef] [PubMed]

14. Stenvinkel, P.; Luttropp, K.; McGuinness, D.; Witasp, A.; Qureshi, A.R.; Wernerson, A.; Nordfors, L.; Schalling, M.; Ripsweden, J.; Wennberg, L.; et al. CDKN2A/p16INK4a expression is associated with vascular progeria in chronic kidney disease. Aging (Albany NY) 2017, 9, 494-507. [CrossRef]

15. Paloian, N.J.; Giachelli, C.M. A current understanding of vascular calcification in CKD. Am. J. Physiol. Ren. Physiol. 2014, 307, F891-F900. [CrossRef]

16. Capusa, C.; Popescu, D. Mechanisms and Clinical Implications of Vascular Calcifications in Chronic Kidney Disease. Chronic Kidney Dis. Pathophysiol. Clin. Improv. 2017. [CrossRef]

17. Wu, M.; Rementer, C.; Giachelli, C.M. Vascular Calcification: An Update on Mechanisms and Challenges in Treatment. Calcif. Tissue Int. 2013, 93, 365-373. [CrossRef]

18. Jaminon, A.; Reesink, K.; Kroon, A.; Schurgers, L. The Role of Vascular Smooth Muscle Cells in Arterial Remodeling: Focus on Calcification-Related Processes. Int. J. Mol. Sci. 2019, 20, 5694. [CrossRef]

19. Liu, M.; Gomez, D. Smooth Muscle Cell Phenotypic Diversity. Arterioscler. Thromb. Vasc. Biol. 2019, 39, 1715-1723. [CrossRef]

20. Durham, A.L.; Speer, M.Y.; Scatena, M.; Giachelli, C.M.; Shanahan, C.M. Role of smooth muscle cells in vascular calcification: Implications in atherosclerosis and arterial stiffness. Cardiovasc. Res. 2018, 114, 590-600. [CrossRef]

21. Leopold, J.A. Vascular calcification: Mechanisms of vascular smooth muscle cell calcification. Trends Cardiovasc. Med. 2015, 25, 267-274. [CrossRef] [PubMed]

22. De Solis, A.J.; González-Pacheco, F.R.; Deudero, J.J.P.; Neria, F.; Albalate, M.; Petkov, V.; Susanibar, L.; Fernandez-Sanchez, R.; Calabia, O.; Ortiz, A.; et al. Alkalinization potentiates vascular calcium deposition in an uremic milieu. J. Nephrol. 2009, 22, 647-653. [PubMed]

23. Cazaña-Pérez, V.; Cidad, P.; Donate-Correa, J.; Martín-Núñez, E.; López-López, J.R.; Pérez-García, M.T.; Giraldez, T.; Navarro-González, J.F.; Alvarez de la Rosa, D. Phenotypic Modulation of Cultured Primary Human Aortic Vascular Smooth Muscle Cells by Uremic Serum. Front. Physiol. 2018, 9, 89. [CrossRef] [PubMed]

24. Ciceri, P.; Galassi, A.; Alfieri, C.; Messa, P.; Cozzolino, M. Uremic Patients with Increased Vascular Calcification Score Have Serum with High Calcific Potential: Role of Vascular Smooth Muscle Cell Osteoblastic Differentiation and Apoptosis. Blood Purif. 2019, 48, 142-149. [CrossRef] [PubMed]

25. Huang, M.; Zheng, L.; Xu, H.; Tang, D.; Lin, L.; Zhang, J.; Li, C.; Wang, W.; Yuan, Q.; Tao, L.; et al. Oxidative stress contributes to vascular calcification in patients with chronic kidney disease. J. Mol. Cell. Cardiol. 2020, 138, 256-268. [CrossRef]

26. Vanholder, R.; Pletinck, A.; Schepers, E.; Glorieux, G. Biochemical and Clinical Impact of Organic Uremic Retention Solutes: A Comprehensive Update. Toxins 2018, 10, 33. [CrossRef]

27. Evenepoel, P.; Poesen, R.; Meijers, B. The gut-kidney axis. Pediatr. Nephrol. 2017, 32, 2005-2014. [CrossRef]

28. Vanholder, R.; De Smet, R.; Glorieux, G.; Argilés, A.; Baurmeister, U.; Brunet, P.; Clark, W.; Cohen, G.; De Deyn, P.P.; Deppisch, R.; et al. Review on uremic toxins: Classification, concentration, and interindividual variability. Kidney Int. 2003, 63, 1934-1943. [CrossRef]

29. Hénaut, L.; Mary, A.; Chillon, J.-M.; Kamel, S.; Massy, Z. The Impact of Uremic Toxins on Vascular Smooth Muscle Cell Function. Toxins 2018, 10, 218. [CrossRef] 
30. Madero, M.; Cano, K.B.; Campos, I.; Tao, X.; Maheshwari, V.; Brown, J.; Cornejo, B.; Handelman, G.; Thijssen, S.; Kotanko, P. Removal of Protein-Bound Uremic Toxins during Hemodialysis Using a Binding Competitor. CJASN 2019, 14, 394-402. [CrossRef]

31. Zhan, J.-K.; Wang, Y.-J.; Wang, Y.; Tang, Z.-Y.; Tan, P.; Huang, W.; Liu, Y.-S. Adiponectin attenuates the osteoblastic differentiation of vascular smooth muscle cells through the AMPK/mTOR pathway. Exp. Cell Res. 2014, 323, 352-358. [CrossRef] [PubMed]

32. Zhan, J.-K.; Wang, Y.-J.; Wang, Y.; Wang, S.; Tan, P.; Huang, W.; Liu, Y.-S. The mammalian target of rapamycin signalling pathway is involved in osteoblastic differentiation of vascular smooth muscle cells. Can. J. Cardiol. 2014, 30, 568-575. [CrossRef] [PubMed]

33. Son, B.-K.; Akishita, M.; Iijima, K.; Kozaki, K.; Maemura, K.; Eto, M.; Ouchi, Y. Adiponectin antagonizes stimulatory effect of tumor necrosis factor-alpha on vascular smooth muscle cell calcification: Regulation of growth arrest-specific gene 6-mediated survival pathway by adenosine 5 '-monophosphate-activated protein kinase. Endocrinology 2008, 149, 1646-1653. [CrossRef] [PubMed]

34. Niknam, S.; Ghatreh-Samani, K.; Farrokhi, E. The effect of adiponectin on osteonectin gene expression by oxidized low density lipoprotein-treated vascular smooth muscle cells. Int. J. Mol. Cell. Med. 2015, 4, 60-66.

35. Lu, Y.; Bian, Y.; Wang, Y.; Bai, R.; Wang, J.; Xiao, C. Globular adiponectin reduces vascular calcification via inhibition of ER-stress-mediated smooth muscle cell apoptosis. Int. J. Clin. Exp. Pathol. 2015, 8, 2545-2554.

36. Luo, X.-H.; Zhao, L.-L.; Yuan, L.-Q.; Wang, M.; Xie, H.; Liao, E.-Y. Development of arterial calcification in adiponectin-deficient mice: Adiponectin regulates arterial calcification. J. Bone Miner. Res. 2009, 24, 1461-1468. [CrossRef]

37. Maahs, D.M.; Ogden, L.G.; Kinney, G.L.; Wadwa, P.; Snell-Bergeon, J.K.; Dabelea, D.; Hokanson, J.E.; Ehrlich, J.; Eckel, R.H.; Rewers, M. Low plasma adiponectin levels predict progression of coronary artery calcification. Circulation 2005, 111, 747-753. [CrossRef]

38. Steffes, M.W.; Gross, M.D.; Lee, D.-H.; Schreiner, P.J.; Jacobs, D.R. Adiponectin, visceral fat, oxidative stress, and early macrovascular disease: The Coronary Artery Risk Development in Young Adults Study. Obesity 2006, 14, 319-326. [CrossRef]

39. Tanna, N.; Patel, K.; Moore, A.E.; Dulnoan, D.; Edwards, S.; Hampson, G. The relationship between circulating adiponectin, leptin and vaspin with bone mineral density (BMD), arterial calcification and stiffness: A cross-sectional study in post-menopausal women. J. Endocrinol. Investig. 2017, 40, 1345-1353. [CrossRef]

40. Aoqui, C.; Cuppari, L.; Kamimura, M.A.; Canziani, M.E.F. Increased visceral adiposity is associated with coronary artery calcification in male patients with chronic kidney disease. Eur. J. Clin. Nutr. 2013, 67, 610-614. [CrossRef]

41. Larsen, B.A.; Laughlin, G.A.; Cummins, K.; Barrett-Connor, E.; Wassel, C.L. Adipokines and severity and progression of coronary artery calcium: Findings from the Rancho Bernardo Study. Atherosclerosis 2017, 265, 1-6. [CrossRef] [PubMed]

42. Värri, M.; Niskanen, L.; Tuomainen, T.; Honkanen, R.; Kröger, H.; Tuppurainen, M.T. Association of adipokines and estradiol with bone and carotid calcifications in postmenopausal women. Climacteric 2016, 19, 204-211. [CrossRef] [PubMed]

43. Hyun, Y.Y.; Kim, H.; Oh, Y.K.; Oh, K.-H.; Ahn, C.; Sung, S.A.; Choi, K.H.; Kim, S.W.; Lee, K.-B. High fibroblast growth factor 23 is associated with coronary calcification in patients with high adiponectin: Analysis from the KoreaN cohort study for Outcome in patients with Chronic Kidney Disease (KNOW-CKD) study. Nephrol. Dial. Transplant. 2019, 34, 123-129. [CrossRef] [PubMed]

44. Mehta, A.; Patel, J.; Al Rifai, M.; Ayers, C.R.; Neeland, I.J.; Kanaya, A.M.; Kandula, N.; Blaha, M.J.; Nasir, K.; Blumenthal, R.S.; et al. Inflammation and coronary artery calcification in South Asians: The Mediators of Atherosclerosis in South Asians Living in America (MASALA) study. Atherosclerosis 2018, 270, 49-56. [CrossRef] [PubMed]

45. Ishihara, T.; Haraguchi, G.; Konishi, M.; Ohigashi, H.; Saito, K.; Nakano, Y.; Isobe, M. Effect of adiponectin on cardiac allograft vasculopathy. Circ. J. 2011, 75, 2005-2012. [CrossRef] [PubMed]

46. Luo, L.; Zheng, W.; Lian, G.; Chen, H.; Li, L.; Xu, C.; Xie, L. Combination treatment of adipose-derived stem cells and adiponectin attenuates pulmonary arterial hypertension in rats by inhibiting pulmonary arterial smooth muscle cell proliferation and regulating the AMPK/BMP/Smad pathway. Int. J. Mol. Med. 2018, 41, 51-60. [CrossRef] 
47. Wang, Y.; Lam, K.S.L.; Xu, J.Y.; Lu, G.; Xu, L.Y.; Cooper, G.J.S.; Xu, A. Adiponectin inhibits cell proliferation by interacting with several growth factors in an oligomerization-dependent manner. J. Biol. Chem. 2005, 280, 18341-18347. [CrossRef]

48. Matsuda, M.; Shimomura, I.; Sata, M.; Arita, Y.; Nishida, M.; Maeda, N.; Kumada, M.; Okamoto, Y.; Nagaretani, H.; Nishizawa, H.; et al. Role of adiponectin in preventing vascular stenosis. The missing link of adipo-vascular axis. J. Biol. Chem. 2002, 277, 37487-37491. [CrossRef]

49. Saneipour, M.; Ghatreh-Samani, K.; Heydarian, E.; Farrokhi, E.; Abdian, N. Adiponectin inhibits oxidized low density lipoprotein-induced increase in matrix metalloproteinase 9 expression in vascular smooth muscle cells. ARYA Atheroscler. 2015, 11, 191-195.

50. Okamoto, Y.; Kihara, S.; Ouchi, N.; Nishida, M.; Arita, Y.; Kumada, M.; Ohashi, K.; Sakai, N.; Shimomura, I.; Kobayashi, H.; et al. Adiponectin reduces atherosclerosis in apolipoprotein E-deficient mice. Circulation 2002, 106, 2767-2770. [CrossRef]

51. Cai, Y.; Teng, X.; Pan, C.; Duan, X.; Tang, C.; Qi, Y. Adrenomedullin up-regulates osteopontin and attenuates vascular calcification via the cAMP/PKA signaling pathway. Acta Pharmacol. Sin. 2010, 31, 1359-1366. [CrossRef] [PubMed]

52. Huang, Z.; Li, J.; Jiang, Z.; Qi, Y.; Tang, C.; Du, J. Effects of adrenomedullin, C-type natriuretic peptide, and parathyroid hormone-related peptide on calcification in cultured rat vascular smooth muscle cells. J. Cardiovasc. Pharmacol. 2003, 42, 89-97. [CrossRef] [PubMed]

53. Zhou, Y.-B.; Gao, Q.; Li, P.; Han, Y.; Zhang, F.; Qi, Y.-F.; Tang, C.-S.; Gao, X.-Y.; Zhu, G.-Q. Adrenomedullin attenuates vascular calcification in fructose-induced insulin resistance rats. Acta Physiol. 2013, 207, 437-446. [CrossRef] [PubMed]

54. Liu, J.; Shimosawa, T.; Matsui, H.; Meng, F.; Supowit, S.C.; DiPette, D.J.; Ando, K.; Fujita, T. Adrenomedullin inhibits angiotensin II-induced oxidative stress via Csk-mediated inhibition of Src activity. Am. J. Physiol. Heart Circ. Physiol. 2007, 292, H1714-H1721. [CrossRef] [PubMed]

55. Yoshimoto, T.; Fukai, N.; Sato, R.; Sugiyama, T.; Ozawa, N.; Shichiri, M.; Hirata, Y. Antioxidant effect of adrenomedullin on angiotensin II-induced reactive oxygen species generation in vascular smooth muscle cells. Endocrinology 2004, 145, 3331-3337. [CrossRef] [PubMed]

56. Shichiri, M.; Fukai, N.; Ozawa, N.; Iwasaki, H.; Hirata, Y. Adrenomedullin is an autocrine/paracrine growth factor for rat vascular smooth muscle cells. Regul. Pept. 2003, 112, 167-173. [CrossRef]

57. Iwasaki, H.; Eguchi, S.; Shichiri, M.; Marumo, F.; Hirata, Y. Adrenomedullin as a novel growth-promoting factor for cultured vascular smooth muscle cells: Role of tyrosine kinase-mediated mitogen-activated protein kinase activation. Endocrinology 1998, 139, 3432-3441. [CrossRef]

58. Kano, H.; Kohno, M.; Yasunari, K.; Yokokawa, K.; Horio, T.; Ikeda, M.; Minami, M.; Hanehira, T.; Takeda, T.; Yoshikawa, J. Adrenomedullin as a novel antiproliferative factor of vascular smooth muscle cells. J. Hypertens. 1996, 14, 209-213. [CrossRef]

59. Ma, J.; Feng, Y.; Li, Z.; Tang, C. The effect of adrenomedullin and proadrenomedullin N-terminal 20 peptide on angiotensin II induced vascular smooth muscle cell proliferation. Iran. J. Basic Med. Sci. 2016, 19, 49-54.

60. Kohno, M.; Yokokawa, K.; Kano, H.; Yasunari, K.; Minami, M.; Hanehira, T.; Yoshikawa, J. Adrenomedullin is a potent inhibitor of angiotensin II-induced migration of human coronary artery smooth muscle cells. Hypertension 1997, 29, 1309-1313. [CrossRef]

61. Horio, T.; Kohno, M.; Kano, H.; Ikeda, M.; Yasunari, K.; Yokokawa, K.; Minami, M.; Takeda, T. Adrenomedullin as a novel antimigration factor of vascular smooth muscle cells. Circ. Res. 1995, 77, 660-664. [CrossRef] [PubMed]

62. Wu, S.Y.; Zhang, B.H.; Pan, C.S.; Jiang, H.F.; Pang, Y.Z.; Tang, C.S.; Qi, Y.F. Endothelin-1 is a potent regulator in vivo in vascular calcification and in vitro in calcification of vascular smooth muscle cells. Peptides 2003, 24, 1149-1156. [CrossRef] [PubMed]

63. Essalihi, R.; Ouellette, V.; Dao, H.H.; McKee, M.D.; Moreau, P. Phenotypic modulation of vascular smooth muscle cells during medial arterial calcification: A role for endothelin? J. Cardiovasc. Pharmacol. 2004, 44 (Suppl. 1), S147-S150. [CrossRef]

64. Larivière, R.; Gauthier-Bastien, A.; Ung, R.-V.; St-Hilaire, J.; Mac-Way, F.; Richard, D.E.; Agharazii, M. Endothelin type A receptor blockade reduces vascular calcification and inflammation in rats with chronic kidney disease. J. Hypertens. 2017, 35, 376-384. [CrossRef] [PubMed] 
65. Wang, F.; Li, T.; Cong, X.; Hou, Z.; Lu, B.; Zhou, Z.; Chen, X. The Value of Big Endothelin-1 in the Assessment of the Severity of Coronary Artery Calcification. Clin. Appl. Thromb. Hemost. 2018, 24, 1042-1049. [CrossRef] [PubMed]

66. Qing, P.; Li, X.-L.; Zhang, Y.; Li, Y.-L.; Xu, R.-X.; Guo, Y.-L.; Li, S.; Wu, N.-Q.; Li, J.-J. Association of Big Endothelin-1 with Coronary Artery Calcification. PLoS ONE 2015, 10, e0142458. [CrossRef]

67. Rebić, D.; Rašić, S.; Hamzić-Mehmedbašić, A.; Džemidžić, J.; Kurtalić, E. Valvular calcification and left ventricular modifying in peritoneal dialysis patients. Ren. Fail. 2015, 37, 1316-1322. [CrossRef]

68. Wedgwood, S.; Dettman, R.W.; Black, S.M. ET-1 stimulates pulmonary arterial smooth muscle cell proliferation via induction of reactive oxygen species. Am. J. Physiol. Lung Cell Mol. Physiol. 2001, 281, L1058-L1067. [CrossRef]

69. Idris-Khodja, N.; Ouerd, S.; Trindade, M.; Gornitsky, J.; Rehman, A.; Barhoumi, T.; Offermanns, S.; Gonzalez, F.J.; Neves, M.F.; Paradis, P.; et al. Vascular smooth muscle cell peroxisome proliferator-activated receptor $\gamma$ protects against endothelin-1-induced oxidative stress and inflammation. J. Hypertens. 2017, 35, 1390-1401. [CrossRef]

70. Trindade, M.; Oigman, W.; Fritsch Neves, M. Potential Role of Endothelin in Early Vascular Aging. Curr. Hypertens. Rev. 2017, 13, 33-40. [CrossRef]

71. Lin, C.-C.; Lin, W.-N.; Hou, W.-C.; Hsiao, L.-D.; Yang, C.-M. Endothelin-1 induces VCAM-1 expressionmediated inflammation via receptor tyrosine kinases and Elk/p300 in human tracheal smooth muscle cells. Am. J. Physiol. Lung Cell Mol. Physiol. 2015, 309, L211-L225. [CrossRef] [PubMed]

72. Kim, F.Y.; Barnes, E.A.; Ying, L.; Chen, C.; Lee, L.; Alvira, C.M.; Cornfield, D.N. Pulmonary artery smooth muscle cell endothelin-1 expression modulates the pulmonary vascular response to chronic hypoxia. Am. J. Physiol. Lung Cell Mol. Physiol. 2015, 308, L368-L377. [CrossRef] [PubMed]

73. Dai, F.; Mao, Z.; Xia, J.; Zhu, S.; Wu, Z. Fluoxetine protects against big endothelin-1 induced anti-apoptosis by rescuing Kv1.5 channels in human pulmonary arterial smooth muscle cells. Yonsei Med. J. 2012, 53, 842-848. [CrossRef] [PubMed]

74. Sauter, G.; Wolf, S.; Risler, T.; Brehm, B. Influence of endothelin receptor antagonism on smooth muscle cell proliferation after chronic renal failure. J. Cardiovasc. Pharmacol. 2004, 44 (Suppl. 1), S165-S167. [CrossRef]

75. Bouallegue, A.; Vardatsikos, G.; Srivastava, A.K. Role of insulin-like growth factor 1 receptor and c-Src in endothelin-1- and angiotensin II-induced PKB phosphorylation, and hypertrophic and proliferative responses in vascular smooth muscle cells. Can. J. Physiol. Pharmacol. 2009, 87, 1009-1018. [CrossRef]

76. Sihvola, R.K.; Pulkkinen, V.P.; Koskinen, P.K.; Lemström, K.B. Crosstalk of endothelin-1 and platelet-derived growth factor in cardiac allograft arteriosclerosis. J. Am. Coll. Cardiol. 2002, 39, 710-717. [CrossRef]

77. Lin, Y.-J.; Juan, C.-C.; Kwok, C.-F.; Hsu, Y.-P.; Shih, K.-C.; Chen, C.-C.; Ho, L.-T. Endothelin-1 exacerbates development of hypertension and atherosclerosis in modest insulin resistant syndrome. Biochem. Biophys. Res. Commun. 2015, 460, 497-503. [CrossRef]

78. Ivey, M.E.; Osman, N.; Little, P.J. Endothelin-1 signalling in vascular smooth muscle: Pathways controlling cellular functions associated with atherosclerosis. Atherosclerosis 2008, 199, 237-247. [CrossRef]

79. Little, P.J.; Ivey, M.E.; Osman, N. Endothelin-1 actions on vascular smooth muscle cell functions as a target for the prevention of atherosclerosis. Curr. Vasc. Pharmacol. 2008, 6, 195-203. [CrossRef]

80. Bouabdallah, J.; Zibara, K.; Issa, H.; Lenglet, G.; Kchour, G.; Caus, T.; Six, I.; Choukroun, G.; Kamel, S.; Bennis, Y. Endothelial cells exposed to phosphate and indoxyl sulphate promote vascular calcification through interleukin-8 secretion. Nephrol. Dial. Transplant. 2019, 34, 1125-1134. [CrossRef]

81. Raaz-Schrauder, D.; Klinghammer, L.; Baum, C.; Frank, T.; Lewczuk, P.; Achenbach, S.; Cicha, I.; Stumpf, C.; Wiltfang, J.; Kornhuber, J.; et al. Association of systemic inflammation markers with the presence and extent of coronary artery calcification. Cytokine 2012, 57, 251-257. [CrossRef] [PubMed]

82. Gauss, S.; Klinghammer, L.; Steinhoff, A.; Raaz-Schrauder, D.; Marwan, M.; Achenbach, S.; Garlichs, C.D. Association of systemic inflammation with epicardial fat and coronary artery calcification. Inflamm. Res. 2015, 64, 313-319. [CrossRef] [PubMed]

83. Hastings, N.E.; Feaver, R.E.; Lee, M.Y.; Wamhoff, B.R.; Blackman, B.R. Human IL-8 regulates smooth muscle cell VCAM-1 expression in response to endothelial cells exposed to atheroprone flow. Arterioscler. Thromb. Vasc. Biol. 2009, 29, 725-731. [CrossRef] 
84. Qin, Y.; Fan, F.; Zhao, Y.; Cui, Y.; Wei, X.; Kohama, K.; Gordon, J.R.; Li, F.; Gao, Y. Recombinant human CXCL8(3-72)K11R/G31P regulates smooth muscle cell proliferation and migration through blockage of interleukin-8 receptor. IUBMB Life 2013, 65, 67-75. [CrossRef] [PubMed]

85. Lv, G.; Zhu, H.; Li, C.; Wang, J.; Zhao, D.; Li, S.; Ma, L.; Sun, G.; Li, F.; Zhao, Y.; et al. Inhibition of IL-8-mediated endothelial adhesion, VSMCs proliferation and migration by siRNA-TMEM98 suggests TMEM98's emerging role in atherosclerosis. Oncotarget 2017, 8, 88043-88058. [CrossRef]

86. Schelski, N.; Luong, T.T.; Lang, F.; Pieske, B.; Voelkl, J.; Alesutan, I. SGK1-Dependent Stimulation of Vascular Smooth Muscle Cell Osteo-/Chondrogenic Transdifferentiation by Interleukin-18. Available online: https://pubmed.ncbi.nlm.nih.gov/30706178/?from_term=il-18+AND+calcification\&from_ size $=50 \&$ from_pos=7 (accessed on 19 March 2020).

87. Zhang, K.; Zhang, Y.; Feng, W.; Chen, R.; Chen, J.; Touyz, R.M.; Wang, J.; Huang, H. Interleukin-18 Enhances Vascular Calcification and Osteogenic Differentiation of Vascular Smooth Muscle Cells through TRPM7 Activation. Arterioscler. Thromb. Vasc. Biol. 2017, 37, 1933-1943. [CrossRef]

88. Wang, B.; Wei, G.; Liu, B.; Zhou, X.; Xiao, H.; Dong, N.; Li, F. The Role of High Mobility Group Box 1 Protein in Interleukin-18-Induced Myofibroblastic Transition of Valvular Interstitial Cells. CRD 2016, 135, 168-178. [CrossRef]

89. Porażko, T.; Kuźniar, J.; Kusztal, M.; Kuźniar, T.J.; Weyde, W.; Kuriata-Kordek, M.; Klinger, M. IL-18 Is Involved in Vascular Injury in End-Stage Renal Disease Patients. Available online: https://pubmed. ncbi.nlm.nih.gov/18775894/?from_term=il-18+AND+calcification\&from_size=50\&from_pos=9 (accessed on 19 March 2020).

90. Kiu Weber, C.I.; Duchateau-Nguyen, G.; Solier, C.; Schell-Steven, A.; Hermosilla, R.; Nogoceke, E.; Block, G. Cardiovascular Risk Markers Associated with Arterial Calcification in Patients with Chronic Kidney Disease Stages 3 and 4. Available online: https://pubmed.ncbi.nlm.nih.gov/24683472/?from_term=il-18+AND+ calcification\&from_size=50\&from_pos=17 (accessed on 19 March 2020).

91. Venkatesan, B.; Valente, A.J.; Reddy, V.S.; Siwik, D.A.; Chandrasekar, B. Resveratrol blocks interleukin-18EMMPRIN cross-regulation and smooth muscle cell migration. Am. J. Physiol. Heart Circ. Physiol. 2009, 297, H874-H886. [CrossRef]

92. Rodriguez-Menocal, L.; Faridi, M.H.; Martinez, L.; Shehadeh, L.A.; Duque, J.C.; Wei, Y.; Mesa, A.; Pena, A.; Gupta, V.; Pham, S.M.; et al. Macrophage-derived IL-18 and increased fibrinogen deposition are age-related inflammatory signatures of vascular remodeling. Am. J. Physiol. Heart Circ. Physiol. 2014, 306, H641-H653. [CrossRef]

93. Sahar, S.; Dwarakanath, R.S.; Reddy, M.A.; Lanting, L.; Todorov, I.; Natarajan, R. Angiotensin II enhances interleukin-18 mediated inflammatory gene expression in vascular smooth muscle cells: A novel cross-talk in the pathogenesis of atherosclerosis. Circ. Res. 2005, 96, 1064-1071. [CrossRef]

94. Chandrasekar, B.; Mummidi, S.; Valente, A.J.; Patel, D.N.; Bailey, S.R.; Freeman, G.L.; Hatano, M.; Tokuhisa, T.; Jensen, L.E. The pro-atherogenic cytokine interleukin-18 induces CXCL16 expression in rat aortic smooth muscle cells via MyD88, interleukin-1 receptor-associated kinase, tumor necrosis factor receptor-associated factor 6, c-Src, phosphatidylinositol 3-kinase, Akt, c-Jun N-terminal kinase, and activator protein-1 signaling. J. Biol. Chem. 2005, 280, 26263-26277. [CrossRef] [PubMed]

95. Lin, Y.-C.; Chiang, C.-H.; Chang, L.-T.; Sun, C.-K.; Leu, S.; Shao, P.-L.; Hsieh, M.-C.; Tsai, T.-H.; Chua, S.; Chung, S.-Y.; et al. Simvastatin attenuates the additive effects of TNF- $\alpha$ and IL-18 on the connexin 43 up-regulation and over-proliferation of cultured aortic smooth muscle cells. Cytokine 2013, 62, 341-351. [CrossRef] [PubMed]

96. Chandrasekar, B.; Mummidi, S.; Mahimainathan, L.; Patel, D.N.; Bailey, S.R.; Imam, S.Z.; Greene, W.C.; Valente, A.J. Interleukin-18-induced human coronary artery smooth muscle cell migration is dependent on NF-kappaB- and AP-1-mediated matrix metalloproteinase-9 expression and is inhibited by atorvastatin. J. Biol. Chem. 2006, 281, 15099-15109. [CrossRef] [PubMed]

97. Valente, A.J.; Yoshida, T.; Izadpanah, R.; Delafontaine, P.; Siebenlist, U.; Chandrasekar, B. Interleukin-18 enhances IL-18R/Nox1 binding, and mediates TRAF3IP2-dependent smooth muscle cell migration. Inhibition by simvastatin. Cell. Signal. 2013, 25, 1447-1456. [CrossRef] [PubMed]

98. Elhage, R.; Jawien, J.; Rudling, M.; Ljunggren, H.-G.; Takeda, K.; Akira, S.; Bayard, F.; Hansson, G.K. Reduced atherosclerosis in interleukin-18 deficient apolipoprotein E-knockout mice. Cardiovasc. Res. 2003, 59, $234-240$. [CrossRef] 
99. Tenger, C.; Sundborger, A.; Jawien, J.; Zhou, X. IL-18 accelerates atherosclerosis accompanied by elevation of IFN-gamma and CXCL16 expression independently of T cells. Arterioscler. Thromb. Vasc. Biol. 2005, 25, 791-796. [CrossRef]

100. Bessueille, L.; Fakhry, M.; Hamade, E.; Badran, B.; Magne, D. Glucose stimulates chondrocyte differentiation of vascular smooth muscle cells and calcification: A possible role for IL-1ß. FEBS Lett. 2015, 589, 2797-2804. [CrossRef]

101. Ceneri, N.; Zhao, L.; Young, B.D.; Healy, A.; Coskun, S.; Vasavada, H.; Yarovinsky, T.O.; Ike, K.; Pardi, R.; Qin, L.; et al. Rac2 Modulates Atherosclerotic Calcification by Regulating Macrophage IL-1 $\beta$ Production. Arterioscler. Thromb. Vasc. Biol. 2017, 37, 328-340. [CrossRef]

102. Han, L.; Zhang, Y.; Zhang, M.; Guo, L.; Wang, J.; Zeng, F.; Xu, D.; Yin, Z.; Xu, Y.; Wang, D.; et al. Interleukin-1 $\beta$-Induced Senescence Promotes Osteoblastic Transition of Vascular Smooth Muscle Cells. Kidney Blood Press. Res. 2020, 45, 314-330. [CrossRef]

103. Dautova, Y.; Kapustin, A.N.; Pappert, K.; Epple, M.; Okkenhaug, H.; Cook, S.J.; Shanahan, C.M.; Bootman, M.D.; Proudfoot, D. Calcium phosphate particles stimulate interleukin- $1 \beta$ release from human vascular smooth muscle cells: A role for spleen tyrosine kinase and exosome release. J. Mol. Cell. Cardiol. 2018, 115, 82-93. [CrossRef]

104. Agharazii, M.; St-Louis, R.; Gautier-Bastien, A.; Ung, R.-V.; Mokas, S.; Larivière, R.; Richard, D.E. Inflammatory cytokines and reactive oxygen species as mediators of chronic kidney disease-related vascular calcification. Am. J. Hypertens. 2015, 28, 746-755. [CrossRef] [PubMed]

105. Awan, Z.; Denis, M.; Roubtsova, A.; Essalmani, R.; Marcinkiewicz, J.; Awan, A.; Gram, H.; Seidah, N.G.; Genest, J. Reducing Vascular Calcification by Anti-IL-1 $\beta$ Monoclonal Antibody in a Mouse Model of Familial Hypercholesterolemia. Angiology 2016, 67, 157-167. [CrossRef] [PubMed]

106. Kraśniak, A.; Drozdz, M.; Pasowicz, M.; Chmiel, G.; Michałek, M.; Szumilak, D.; Podolec, P.; Klimeczek, P.; Konieczyńska, M.; Wicher-Muniak, E.; et al. Factors involved in vascular calcification and atherosclerosis in maintenance haemodialysis patients. Nephrol. Dial. Transplant. 2007, 22, 515-521. [CrossRef] [PubMed]

107. Ikeda, K.; Souma, Y.; Akakabe, Y.; Kitamura, Y.; Matsuo, K.; Shimoda, Y.; Ueyama, T.; Matoba, S.; Yamada, H.; Okigaki, M.; et al. Macrophages play a unique role in the plaque calcification by enhancing the osteogenic signals exerted by vascular smooth muscle cells. Biochem. Biophys. Res. Commun. 2012, 425, 39-44. [CrossRef] [PubMed]

108. Hoare, G.S.; Marczin, N.; Chester, A.H.; Yacoub, M.H. Role of oxidant stress in cytokine-induced activation of NF-kappaB in human aortic smooth muscle cells. Am. J. Physiol. 1999, 277, H1975-H1984. [CrossRef] [PubMed]

109. Alexander, M.R.; Murgai, M.; Moehle, C.W.; Owens, G.K. Interleukin-1ß modulates smooth muscle cell phenotype to a distinct inflammatory state relative to PDGF-DD via NF-KB-dependent mechanisms. Physiol. Genom. 2012, 44, 417-429. [CrossRef]

110. Lim, J.H.; Um, H.J.; Park, J.-W.; Lee, I.-K.; Kwon, T.K. Interleukin-1beta promotes the expression of monocyte chemoattractant protein-1 in human aorta smooth muscle cells via multiple signaling pathways. Exp. Mol. Med. 2009, 41, 757-764. [CrossRef]

111. Geng, Y.J.; Henderson, L.E.; Levesque, E.B.; Muszynski, M.; Libby, P. Fas is expressed in human atherosclerotic intima and promotes apoptosis of cytokine-primed human vascular smooth muscle cells. Arterioscler. Thromb. Vasc. Biol. 1997, 17, 2200-2208. [CrossRef]

112. Geng, Y.J.; Wu, Q.; Muszynski, M.; Hansson, G.K.; Libby, P. Apoptosis of vascular smooth muscle cells induced by in vitro stimulation with interferon-gamma, tumor necrosis factor-alpha, and interleukin-1 beta. Arterioscler. Thromb. Vasc. Biol. 1996, 16, 19-27. [CrossRef]

113. Wang, X.; Chen, L.; Liu, J.; Yan, T.; Wu, G.; Xia, Y.; Zong, G.; Li, F. In vivo treatment of rat arterial adventitia with interleukin-1 $\beta$ induces intimal proliferation via the JAK2/STAT3 signaling pathway. Mol. Med. Rep. 2016, 13, 3451-3458. [CrossRef]

114. Kim, H.J.; Kim, M.Y.; Hwang, J.S.; Kim, H.J.; Lee, J.H.; Chang, K.C.; Kim, J.-H.; Han, C.W.; Kim, J.-H.; Seo, H.G. PPARdelta inhibits IL-1beta-stimulated proliferation and migration of vascular smooth muscle cells via up-regulation of IL-1Ra. Cell. Mol. Life Sci. 2010, 67, 2119-2130. [CrossRef] [PubMed]

115. Wang, Z.; Kong, L.; Kang, J.; Vaughn, D.M.; Bush, G.D.; Walding, A.L.; Grigorian, A.A.; Robinson, J.S.; Nakayama, D.K. Interleukin-1 $\beta$ induces migration of rat arterial smooth muscle cells through a mechanism involving increased matrix metalloproteinase-2 activity. J. Surg. Res. 2011, 169, 328-336. [CrossRef] [PubMed] 
116. Khan, R.; Rheaume, E.; Tardif, J.-C. Examining the Role of and Treatment Directed at IL-1 $\beta$ in Atherosclerosis. Curr. Atheroscler. Rep. 2018, 20, 53. [CrossRef] [PubMed]

117. Deuell, K.A.; Callegari, A.; Giachelli, C.M.; Rosenfeld, M.E.; Scatena, M. RANKL enhances macrophage paracrine pro-calcific activity in high phosphate-treated smooth muscle cells: Dependence on IL-6 and TNF- $\alpha$. J. Vasc. Res. 2012, 49, 510-521. [CrossRef] [PubMed]

118. Callegari, A.; Coons, M.L.; Ricks, J.L.; Rosenfeld, M.E.; Scatena, M. Increased Calcification in Osteoprotegerin Deficient Smooth Muscle Cells: Dependence on Receptor Activator of NF-кB Ligand and Interleukin-6. J. Vasc. Res. 2014, 51, 118-131. [CrossRef]

119. Yao, Y.; Watson, A.D.; Ji, S.; Boström, K.I. Heat shock protein 70 enhances vascular bone morphogenetic protein-4 signaling by binding matrix Gla protein. Circ. Res. 2009, 105, 575-584. [CrossRef]

120. Sun, M.; Chang, Q.; Xin, M.; Wang, Q.; Li, H.; Qian, J. Endogenous bone morphogenetic protein 2 plays a role in vascular smooth muscle cell calcification induced by interleukin 6 in vitro. Int. J. Immunopathol. Pharmacol. 2017, 30, 227-237. [CrossRef]

121. Xu, D.; Zeng, F.; Han, L.; Wang, J.; Yin, Z.; Lv, L.; Guo, L.; Wang, D.; Xu, Y.; Zhou, H. The synergistic action of phosphate and interleukin-6 enhances senescence-associated calcification in vascular smooth muscle cells depending on p53. Mech. Ageing Dev. 2019, 182, 111124. [CrossRef]

122. Kurozumi, A.; Nakano, K.; Yamagata, K.; Okada, Y.; Nakayamada, S.; Tanaka, Y. IL-6 and sIL-6R induces STAT3-dependent differentiation of human VSMCs into osteoblast-like cells through JMJD2B-mediated histone demethylation of RUNX2. Bone 2019, 124, 53-61. [CrossRef]

123. Lee, G.L.; Yeh, C.C.; Wu, J.Y.; Lin, H.C.; Wang, Y.F.; Kuo, Y.Y.; Hsieh, Y.T.; Hsu, Y.J.; Kuo, C.C. TLR2 Promotes Vascular Smooth Muscle Cell Chondrogenic Differentiation and Consequent Calcification via the Concerted Actions of Osteoprotegerin Suppression and IL-6-Mediated RANKL Induction. Arterioscler. Thromb. Vasc. Biol. 2019, 39, 432-445. [CrossRef]

124. Shavelle, D.M.; Katz, R.; Takasu, J.; Lima, J.A.; Jenny, N.S.; Budoff, M.J.; O’Brien, K.D. Soluble intercellular adhesion molecule-1 (sICAM-1) and aortic valve calcification in the multi-ethnic study of atherosclerosis (MESA). J. Heart Valve Dis. 2008, 17, 388-395. [PubMed]

125. Takasu, J.; Katz, R.; Shavelle, D.M.; O’Brien, K.; Mao, S.; Carr, J.J.; Cushman, M.; Budoff, M.J. Inflammation and descending thoracic aortic calcification as detected by computed tomography: The Multi-Ethnic Study of Atherosclerosis. Atherosclerosis 2008, 199, 201-206. [CrossRef] [PubMed]

126. Chen, Z.; Qureshi, A.R.; Parini, P.; Hurt-Camejo, E.; Ripsweden, J.; Brismar, T.B.; Barany, P.; Jaminon, A.M.; Schurgers, L.J.; Heimbürger, O.; et al. Does statins promote vascular calcification in chronic kidney disease? Eur. J. Clin. Investig. 2017, 47, 137-148. [CrossRef] [PubMed]

127. Barreto, D.V.; Barreto, F.C.; Liabeuf, S.; Temmar, M.; Lemke, H.-D.; Tribouilloy, C.; Choukroun, G.; Vanholder, R.; Massy, Z.A.; European Uremic Toxin Work Group (EUTox). Plasma interleukin-6 is independently associated with mortality in both hemodialysis and pre-dialysis patients with chronic kidney disease. Kidney Int. 2010, 77, 550-556. [CrossRef]

128. He, J.; Reilly, M.; Yang, W.; Chen, J.; Go, A.S.; Lash, J.P.; Rahman, M.; DeFilippi, C.; Gadegbeku, C.; Kanthety, R.; et al. Risk factors for coronary artery calcium among patients with chronic kidney disease (from the Chronic Renal Insufficiency Cohort Study). Am. J. Cardiol. 2012, 110, 1735-1741. [CrossRef] [PubMed]

129. Bundy, J.D.; Chen, J.; Yang, W.; Budoff, M.; Go, A.S.; Grunwald, J.E.; Kallem, R.R.; Post, W.S.; Reilly, M.P.; Ricardo, A.C.; et al. Risk factors for progression of coronary artery calcification in patients with chronic kidney disease: The CRIC study. Atherosclerosis 2018, 271, 53-60. [CrossRef]

130. Liu, Y.; Shanahan, C.M. Signalling pathways and vascular calcification. Front. Biosci. (Landmark Ed.) 2011, 16, 1302-1314. [CrossRef]

131. Wassmann, S.; Stumpf, M.; Strehlow, K.; Schmid, A.; Schieffer, B.; Böhm, M.; Nickenig, G. Interleukin-6 induces oxidative stress and endothelial dysfunction by overexpression of the angiotensin II type 1 receptor. Circ. Res. 2004, 94, 534-541. [CrossRef]

132. Den Dekker, W.K.; Tempel, D.; Bot, I.; Biessen, E.A.; Joosten, L.A.; Netea, M.G.; Van der Meer, J.W.M.; Cheng, C.; Duckers, H.J. Mast cells induce vascular smooth muscle cell apoptosis via a toll-like receptor 4 activation pathway. Arterioscler. Thromb. Vasc. Biol. 2012, 32, 1960-1969. [CrossRef]

133. Wang, Q.; Shu, C.; Su, J.; Li, X. A crosstalk triggered by hypoxia and maintained by MCP-1/miR-98/IL-6/p38 regulatory loop between human aortic smooth muscle cells and macrophages leads to aortic smooth muscle cells apoptosis via Stat1 activation. Int. J. Clin. Exp. Pathol. 2015, 8, 2670-2679. 
134. Knobloch, J.; Yanik, S.D.; Körber, S.; Stoelben, E.; Jungck, D.; Koch, A. TNF $\alpha$-induced airway smooth muscle cell proliferation depends on endothelin receptor signaling, GM-CSF and IL-6. Biochem. Pharmacol. 2016, 116, 188-199. [CrossRef] [PubMed]

135. Xiang, S.; Dong, N.-G.; Liu, J.-P.; Wang, Y.; Shi, J.-W.; Wei, Z.-J.; Hu, X.-J.; Gong, L. Inhibitory effects of suppressor of cytokine signaling 3 on inflammatory cytokine expression and migration and proliferation of IL-6/IFN- $\gamma$-induced vascular smooth muscle cells. J. Huazhong Univ. Sci. Technol. Med. Sci. 2013, 33, 615-622. [CrossRef] [PubMed]

136. Lee, G.-L.; Wu, J.-Y.; Tsai, C.-S.; Lin, C.-Y.; Tsai, Y.-T.; Lin, C.-S.; Wang, Y.-F.; Yet, S.-F.; Hsu, Y.-J.; Kuo, C.-C. TLR4-Activated MAPK-IL-6 Axis Regulates Vascular Smooth Muscle Cell Function. Int. J. Mol. Sci. 2016, 17, 1394. [CrossRef] [PubMed]

137. Carrillo-López, N.; Panizo, S.; Alonso-Montes, C.; Martínez-Arias, L.; Avello, N.; Sosa, P.; Dusso, A.S.; Cannata-Andía, J.B.; Naves-Díaz, M. High-serum phosphate and parathyroid hormone distinctly regulate bone loss and vascular calcification in experimental chronic kidney disease. Nephrol. Dial. Transplant. 2019, 34, 934-941. [CrossRef] [PubMed]

138. Patidar, A.; Singh, D.K.; Winocour, P.; Farrington, K.; Baydoun, A.R. Human uraemic serum displays calcific potential in vitro that increases with advancing chronic kidney disease. Clin. Sci. 2013, 125, 237-245. [CrossRef]

139. Graciolli, F.G.; Neves, K.R.; dos Reis, L.M.; Graciolli, R.G.; Noronha, I.L.; Moysés, R.M.A.; Jorgetti, V. Phosphorus overload and PTH induce aortic expression of Runx2 in experimental uraemia. Nephrol. Dial. Transplant. 2009, 24, 1416-1421. [CrossRef]

140. Neves, K.R.; Graciolli, F.G.; dos Reis, L.M.; Graciolli, R.G.; Neves, C.L.; Magalhães, A.O.; Custódio, M.R.; Batista, D.G.; Jorgetti, V.; Moysés, R.M.A. Vascular calcification: Contribution of parathyroid hormone in renal failure. Kidney Int. 2007, 71, 1262-1270. [CrossRef]

141. Cheng, S.-L.; Shao, J.-S.; Halstead, L.R.; Distelhorst, K.; Sierra, O.; Towler, D.A. Activation of vascular smooth muscle parathyroid hormone receptor inhibits Wnt/beta-catenin signaling and aortic fibrosis in diabetic arteriosclerosis. Circ. Res. 2010, 107, 271-282. [CrossRef]

142. Shao, J.-S.; Cheng, S.-L.; Charlton-Kachigian, N.; Loewy, A.P.; Towler, D.A. Teriparatide (human parathyroid hormone (1-34)) inhibits osteogenic vascular calcification in diabetic low density lipoprotein receptor-deficient mice. J. Biol. Chem. 2003, 278, 50195-50202. [CrossRef]

143. Malluche, H.H.; Blomquist, G.; Monier-Faugere, M.-C.; Cantor, T.L.; Davenport, D.L. High Parathyroid Hormone Level and Osteoporosis Predict Progression of Coronary Artery Calcification in Patients on Dialysis. J. Am. Soc. Nephrol. 2015, 26, 2534-2544. [CrossRef]

144. Gulcicek, S.; Zoccali, C.; Olgun, D.Ç.; Tripepi, G.; Alagoz, S.; Yalın, S.F.; Trabulus, S.; Altiparmak, M.R.; Seyahi, N. Long-Term Progression of Coronary Artery Calcification Is Independent of Classical Risk Factors, C-Reactive Protein, and Parathyroid Hormone in Renal Transplant Patients. Cardiorenal Med. 2017, 7, 284-294. [CrossRef] [PubMed]

145. Perkovic, V.; Hewitson, T.D.; Kelynack, K.J.; Martic, M.; Tait, M.G.; Becker, G.J. Parathyroid hormone has a prosclerotic effect on vascular smooth muscle cells. Kidney Blood Press. Res. 2003, 26, 27-33. [CrossRef] [PubMed]

146. Yamauchi, H.; Motomura, N.; Chung, U.-I.; Sata, M.; Takai, D.; Saito, A.; Ono, M.; Takamoto, S. Growth-associated hyperphosphatemia in young recipients accelerates aortic allograft calcification in a rat model. J. Thorac. Cardiovasc. Surg. 2013, 145, 522-530. [CrossRef] [PubMed]

147. Kawada, S.; Nagasawa, Y.; Kawabe, M.; Ohyama, H.; Kida, A.; Kato-Kogoe, N.; Nanami, M.; Hasuike, Y.; Kuragano, T.; Kishimoto, H.; et al. Iron-induced calcification in human aortic vascular smooth muscle cells through interleukin-24 (IL-24), with/without TNF-alpha. Sci. Rep. 2018, 8, 1-11. [CrossRef] [PubMed]

148. Shioi, A.; Katagi, M.; Okuno, Y.; Mori, K.; Jono, S.; Koyama, H.; Nishizawa, Y. Induction of bone-type alkaline phosphatase in human vascular smooth muscle cells: Roles of tumor necrosis factor-alpha and oncostatin $\mathrm{M}$ derived from macrophages. Circ. Res. 2002, 91, 9-16. [CrossRef] [PubMed]

149. Lee, H.-L.; Woo, K.M.; Ryoo, H.-M.; Baek, J.-H. Tumor necrosis factor-alpha increases alkaline phosphatase expression in vascular smooth muscle cells via MSX2 induction. Biochem. Biophys. Res. Commun. 2010, 391, 1087-1092. [CrossRef] 
150. Aghagolzadeh, P.; Bachtler, M.; Bijarnia, R.; Jackson, C.; Smith, E.R.; Odermatt, A.; Radpour, R.; Pasch, A. Calcification of vascular smooth muscle cells is induced by secondary calciprotein particles and enhanced by tumor necrosis factor- $\alpha$. Atherosclerosis 2016, 251, 404-414. [CrossRef]

151. Ye, Y.; Bian, W.; Fu, F.; Hu, J.; Liu, H. Selenoprotein S inhibits inflammation-induced vascular smooth muscle cell calcification. J. Biol. Inorg. Chem. 2018, 23, 739-751. [CrossRef]

152. Zickler, D.; Luecht, C.; Willy, K.; Chen, L.; Witowski, J.; Girndt, M.; Fiedler, R.; Storr, M.; Kamhieh-Milz, J.; Schoon, J.; et al. Tumour necrosis factor-alpha in uraemic serum promotes osteoblastic transition and calcification of vascular smooth muscle cells via extracellular signal-regulated kinases and activator protein 1/c-FOS-mediated induction of interleukin 6 expression. Nephrol. Dial. Transplant. 2018, 33, 574-585. [CrossRef]

153. García-Miguel, M.; Riquelme, J.A.; Norambuena-Soto, I.; Morales, P.E.; Sanhueza-Olivares, F.; Nuñez-Soto, C.; Mondaca-Ruff, D.; Cancino-Arenas, N.; San Martín, A.; Chiong, M. Autophagy mediates tumor necrosis factor- $\alpha$-induced phenotype switching in vascular smooth muscle A7r5 cell line. PLoS ONE 2018, 13, e0197210. [CrossRef]

154. Freise, C.; Querfeld, U. The lignan (+)-episesamin interferes with TNF- $\alpha$-induced activation of VSMC via diminished activation of NF-kB, ERK1/2 and AKT and decreased activity of gelatinases. Acta Physiol. 2015, 213, 642-652. [CrossRef] [PubMed]

155. Choi, H.; Dikalova, A.; Stark, R.J.; Lamb, F.S. c-Jun N-terminal kinase attenuates TNF $\alpha$ signaling by reducing Nox1-dependent endosomal ROS production in vascular smooth muscle cells. Free Radic. Biol. Med. 2015, 86, 219-227. [CrossRef] [PubMed]

156. Cao, Q.; Jiang, Y.; Shi, J.; Xu, C.; Liu, X.; Yang, T.; Fu, P.; Niu, T. Artemisinin inhibits the proliferation, migration, and inflammatory reaction induced by tumor necrosis factor- $\alpha$ in vascular smooth muscle cells through nuclear factor kappa B pathway. J. Surg. Res. 2015, 194, 667-678. [CrossRef] [PubMed]

157. Kazama, K.; Usui, T.; Okada, M.; Hara, Y.; Yamawaki, H. Omentin plays an anti-inflammatory role through inhibition of TNF- $\alpha$-induced superoxide production in vascular smooth muscle cells. Eur. J. Pharmacol. 2012, 686, 116-123. [CrossRef] [PubMed]

158. Tang, M.; Fang, J. TNF- $\alpha$ regulates apoptosis of human vascular smooth muscle cells through gap junctions. Mol. Med. Rep. 2017, 15, 1407-1411. [CrossRef] [PubMed]

159. Tang, V.; Dhirapong, A.; Yabes, A.P.; Weiss, R.H. TNF-alpha-mediated apoptosis in vascular smooth muscle cells requires p73. Am. J. Physiol. Cell Physiol. 2005, 289, C199-C206. [CrossRef] [PubMed]

160. Jin, Y.-H.; Kim, S.-A. 2-Methoxycinnamaldehyde inhibits the TNF- $\alpha$-induced proliferation and migration of human aortic smooth muscle cells. Int. J. Mol. Med. 2017, 39, 191-198. [CrossRef] [PubMed]

161. Li, H.; Liang, J.; Castrillon, D.H.; DePinho, R.A.; Olson, E.N.; Liu, Z.-P. FoxO4 regulates tumor necrosis factor alpha-directed smooth muscle cell migration by activating matrix metalloproteinase 9 gene transcription. Mol. Cell. Biol. 2007, 27, 2676-2686. [CrossRef]

162. Goetze, S.; Xi, X.P.; Kawano, Y.; Kawano, H.; Fleck, E.; Hsueh, W.A.; Law, R.E. TNF-alpha-induced migration of vascular smooth muscle cells is MAPK dependent. Hypertension 1999, 33, 183-189. [CrossRef]

163. Kleinbongard, P.; Heusch, G.; Schulz, R. TNFalpha in atherosclerosis, myocardial ischemia/reperfusion and heart failure. Pharmacol. Ther. 2010, 127, 295-314. [CrossRef]

164. Brånén, L.; Hovgaard, L.; Nitulescu, M.; Bengtsson, E.; Nilsson, J.; Jovinge, S. Inhibition of tumor necrosis factor-alpha reduces atherosclerosis in apolipoprotein E knockout mice. Arterioscler. Thromb. Vasc. Biol. 2004, 24, 2137-2142. [CrossRef] [PubMed]

165. Van Campenhout, A.; Moran, C.S.; Parr, A.; Clancy, P.; Rush, C.; Jakubowski, H.; Golledge, J. Role of homocysteine in aortic calcification and osteogenic cell differentiation. Atherosclerosis 2009, 202, 557-566. [CrossRef] [PubMed]

166. Liu, T.; Lin, J.; Ju, T.; Chu, L.; Zhang, L. Vascular smooth muscle cell differentiation to an osteogenic phenotype involves matrix metalloproteinase-2 modulation by homocysteine. Mol. Cell. Biochem. 2015, 406, 139-149. [CrossRef] [PubMed]

167. Li, J.; Chai, S.; Tang, C.; Du, J. Homocysteine potentiates calcification of cultured rat aortic smooth muscle cells. Life Sci. 2003, 74, 451-461. [CrossRef] [PubMed]

168. Ren, J.-L.; Hou, Y.-L.; Ni, X.-Q.; Zhu, Q.; Chen, Y.; Zhang, L.-S.; Liu, X.; Xue, C.-D.; Wu, N.; Yu, Y.-R.; et al. Intermedin1-53 Ameliorates Homocysteine-Promoted Atherosclerotic Calcification by Inhibiting Endoplasmic Reticulum Stress. J. Cardiovasc. Pharmacol. Ther. 2020, 25, 251-264. [CrossRef] 
169. Zhu, L.; Zhang, N.; Yan, R.; Yang, W.; Cong, G.; Yan, N.; Ma, W.; Hou, J.; Yang, L.; Jia, S. Hyperhomocysteinemia induces vascular calcification by activating the transcription factor RUNX2 via Krüppel-like factor 4 up-regulation in mice. J. Biol. Chem. 2019, 294, 19465-19474. [CrossRef]

170. Kim, B.J.; Kim, B.S.; Kang, J.H. Plasma homocysteine and coronary artery calcification in Korean men. Eur. J. Prev. Cardiol. 2015, 22, 478-485. [CrossRef]

171. Peña-Duque, M.A.; Baños-González, M.A.; Valente-Acosta, B.; Rodríguez-Lobato, L.G.; Martínez-Ríos, M.A.; Cardoso-Saldaña, G.; Barragán-García, R.; Herrera-Alarcón, V.; Linares-López, C.; Delgado-Granados, H.; et al. Homocysteine is related to aortic mineralization in patients with ischemic heart disease. J. Atheroscler. Thromb. 2012, 19, 292-297. [CrossRef]

172. Kronenberg, F.; Mündle, M.; Längle, M.; Neyer, U. Prevalence and progression of peripheral arterial calcifications in patients with ESRD. Am. J. Kidney Dis. 2003, 41, 140-148. [CrossRef]

173. Rasouli, M.L.; Nasir, K.; Blumenthal, R.S.; Park, R.; Aziz, D.C.; Budoff, M.J. Plasma homocysteine predicts progression of atherosclerosis. Atherosclerosis 2005, 181, 159-165. [CrossRef]

174. Kullo, I.J.; Li, G.; Bielak, L.F.; Bailey, K.R.; Sheedy, P.F.; Peyser, P.A.; Turner, S.T.; Kardia, S.L.R. Association of plasma homocysteine with coronary artery calcification in different categories of coronary heart disease risk. Mayo Clin. Proc. 2006, 81, 177-182. [CrossRef] [PubMed]

175. Baber, U.; de Lemos, J.A.; Khera, A.; McGuire, D.K.; Omland, T.; Toto, R.D.; Hedayati, S.S. Non-traditional risk factors predict coronary calcification in chronic kidney disease in a population-based cohort. Kidney Int. 2008, 73, 615-621. [CrossRef] [PubMed]

176. Held, C.; Sumner, G.; Sheridan, P.; McQueen, M.; Smith, S.; Dagenais, G.; Yusuf, S.; Lonn, E. Correlations between plasma homocysteine and folate concentrations and carotid atherosclerosis in high-risk individuals: Baseline data from the Homocysteine and Atherosclerosis Reduction Trial (HART). Vasc. Med. 2008, 13, 245-253. [CrossRef] [PubMed]

177. Karger, A.B.; Steffen, B.T.; Nomura, S.O.; Guan, W.; Garg, P.K.; Szklo, M.; Budoff, M.J.; Tsai, M.Y. Association between Homocysteine and Vascular Calcification Incidence, Prevalence, and Progression in the MESA Cohort. J. Am. Heart Assoc. 2020, 9, e013934. [CrossRef]

178. Novaro, G.M.; Aronow, H.D.; Mayer-Sabik, E.; Griffin, B.P. Plasma homocysteine and calcific aortic valve disease. Heart 2004, 90, 802-803. [CrossRef]

179. de Menezes, F.L.; Koch-Nogueira, P.C.; do Val, M.L.D.M.; Pestana, J.O.M.; Jorgetti, V.; Dos Reis, M.A.; Dos Reis Monteiro, M.L.G.; Leite, H.P. Is arterial calcification in children and adolescents with end-stage renal disease a rare finding? Nephrology 2019, 24, 696-702. [CrossRef]

180. Godsland, I.F.; Elkeles, R.S.; Feher, M.D.; Nugara, F.; Rubens, M.B.; Richmond, W.; Khan, M.; Donovan, J.; Anyaoku, V.; Flather, M.D.; et al. Coronary calcification, homocysteine, C-reactive protein and the metabolic syndrome in Type 2 diabetes: The Prospective Evaluation of Diabetic Ischaemic Heart Disease by Coronary Tomography (PREDICT) Study. Diabet. Med. 2006, 23, 1192-1200. [CrossRef]

181. Krajnc, M.; Pečovnik Balon, B.; Krajnc, I. Non-traditional risk factors for coronary calcification and its progression in patients with type 2 diabetes: The impact of postprandial glycemia and fetuin-A. J. Int. Med. Res. 2019, 47, 846-858. [CrossRef]

182. Ke, X.D.; Foucault-Bertaud, A.; Genovesio, C.; Dignat-George, F.; Lamy, E.; Charpiot, P. Homocysteine modulates the proteolytic potential of human arterial smooth muscle cells through a reactive oxygen species dependant mechanism. Mol. Cell. Biochem. 2010, 335, 203-210. [CrossRef]

183. Chang, L.; Xu, J.; Zhao, J.; Pang, Y.; Tang, C.; Qi, Y. Taurine antagonized oxidative stress injury induced by homocysteine in rat vascular smooth muscle cells. Acta Pharmacol. Sin. 2004, 25, 341-346.

184. Zhang, L.; Jin, M.; Hu, X.-S.; Zhu, J.-H. Homocysteine stimulates nuclear factor kappaB activity and interleukin-6 expression in rat vascular smooth muscle cells. Cell Biol. Int. 2006, 30, 592-597. [CrossRef] [PubMed]

185. Pang, X.; Liu, J.; Zhao, J.; Mao, J.; Zhang, X.; Feng, L.; Han, C.; Li, M.; Wang, S.; Wu, D. Homocysteine induces the expression of C-reactive protein via NMDAr-ROS-MAPK-NF-кB signal pathway in rat vascular smooth muscle cells. Atherosclerosis 2014, 236, 73-81. [CrossRef] [PubMed]

186. Su, J.; Wang, S.; Hunag, Y.; Jinag, Y. A comparative study on pathogenic effects of homocysteine and cysteine on atherosclerosis. Wei Sheng Yan Jiu 2009, 38, 43-46. [PubMed] 
187. Buemi, M.; Marino, D.; Di Pasquale, G.; Floccari, F.; Ruello, A.; Aloisi, C.; Corica, F.; Senatore, M.; Romeo, A.; Frisina, N. Effects of homocysteine on proliferation, necrosis, and apoptosis of vascular smooth muscle cells in culture and influence of folic acid. Thromb. Res. 2001, 104, 207-213. [CrossRef]

188. Rasmussen, L.M.; Hansen, P.R.; Ledet, T. Homocysteine and the production of collagens, proliferation and apoptosis in human arterial smooth muscle cells. APMIS 2004, 112, 598-604. [CrossRef] [PubMed]

189. Zhang, H.-P.; Wang, Y.-H.; Cao, C.-J.; Yang, X.-M.; Ma, S.-C.; Han, X.-B.; Yang, X.-L.; Yang, A.-N.; Tian, J.; $\mathrm{Xu}, \mathrm{H}$.; et al. A regulatory circuit involving miR-143 and DNMT3a mediates vascular smooth muscle cell proliferation induced by homocysteine. Mol. Med. Rep. 2016, 13, 483-490. [CrossRef] [PubMed]

190. Ma, S.-C.; Zhang, H.-P.; Jiao, Y.; Wang, Y.-H.; Zhang, H.; Yang, X.-L.; Yang, A.-N.; Jiang, Y.-D. Homocysteineinduced proliferation of vascular smooth muscle cells occurs via PTEN hypermethylation and is mitigated by Resveratrol. Mol. Med. Rep. 2018, 17, 5312-5319. [CrossRef]

191. Bao, X.; Zheng, H. Atorvastatin attenuates homocysteine-induced migration of smooth muscle cells through mevalonate pathway involving reactive oxygen species and p38 MAPK. Clin. Exp. Pharmacol. Physiol. 2015, 42, 865-873. [CrossRef]

192. Jiang, C.; Zhang, H.; Zhang, W.; Kong, W.; Zhu, Y.; Zhang, H.; Xu, Q.; Li, Y.; Wang, X. Homocysteine promotes vascular smooth muscle cell migration by induction of the adipokine resistin. Am. J. Physiol. Cell Physiol. 2009, 297, C1466-C1476. [CrossRef] [PubMed]

193. Zhao, J.; Chen, H.; Liu, N.; Chen, J.; Gu, Y.; Chen, J.; Yang, K. Role of Hyperhomocysteinemia and Hyperuricemia in Pathogenesis of Atherosclerosis. J. Stroke Cerebrovasc. Dis. 2017, 26, 2695-2699. [CrossRef]

194. Chen, Y.; Liu, R.; Zhang, G.; Yu, Q.; Jia, M.; Zheng, C.; Wang, Y.; Xu, C.; Zhang, Y.; Liu, E. Hypercysteinemia promotes atherosclerosis by reducing protein S-nitrosylation. Biomed. Pharmacother. 2015, 70, 253-259. [CrossRef] [PubMed]

195. Chen, J.; Zhang, X.; Zhang, H.; Liu, T.; Zhang, H.; Teng, J.; Ji, J.; Ding, X. Indoxyl Sulfate Enhance the Hypermethylation of Klotho and Promote the Process of Vascular Calcification in Chronic Kidney Disease. Int. J. Biol. Sci. 2016, 12, 1236-1246. [CrossRef] [PubMed]

196. Zhang, H.; Chen, J.; Shen, Z.; Gu, Y.; Xu, L.; Hu, J.; Zhang, X.; Ding, X. Indoxyl sulfate accelerates vascular smooth muscle cell calcification via microRNA-29b dependent regulation of $\mathrm{Wnt} / \beta$-catenin signaling. Toxicol. Lett. 2018, 284, 29-36. [CrossRef] [PubMed]

197. Wu, Y.; Han, X.; Wang, L.; Diao, Z.; Liu, W. Indoxyl sulfate promotes vascular smooth muscle cell calcification via the JNK/Pit-1 pathway. Ren. Fail. 2016, 38, 1702-1710. [CrossRef] [PubMed]

198. Opdebeeck, B.; Maudsley, S.; Azmi, A.; De Maré, A.; De Leger, W.; Meijers, B.; Verhulst, A.; Evenepoel, P.; D'Haese, P.C.; Neven, E. Indoxyl Sulfate and p-Cresyl Sulfate Promote Vascular Calcification and Associate with Glucose Intolerance. J. Am. Soc. Nephrol. JASN 2019, 30, 751-766. [CrossRef]

199. Asami, M.; Tanabe, K.; Ito, S.; Yoshida, E.; Aoki, J.; Tanimoto, S.; Horiuchi, Y.; Yoshida, M. Impact of Indoxyl Sulfate on Coronary Plaques in Patients on Hemodialysis. Int. Heart J. 2018, 59, 489-496. [CrossRef]

200. Barreto, F.C.; Barreto, D.V.; Liabeuf, S.; Meert, N.; Glorieux, G.; Temmar, M.; Choukroun, G.; Vanholder, R.; Massy, Z.A.; European Uremic Toxin Work Group (EUTox). Serum indoxyl sulfate is associated with vascular disease and mortality in chronic kidney disease patients. Clin. J. Am. Soc. Nephrol. 2009, 4, 1551-1558. [CrossRef]

201. Taki, K.; Takayama, F.; Tsuruta, Y.; Niwa, T. Oxidative stress, advanced glycation end product, and coronary artery calcification in hemodialysis patients. Kidney Int. 2006, 70, 218-224. [CrossRef]

202. Muteliefu, G.; Enomoto, A.; Jiang, P.; Takahashi, M.; Niwa, T. Indoxyl sulphate induces oxidative stress and the expression of osteoblast-specific proteins in vascular smooth muscle cells. Nephrol. Dial. Transplant. 2009, 24, 2051-2058. [CrossRef]

203. Muteliefu, G.; Shimizu, H.; Enomoto, A.; Nishijima, F.; Takahashi, M.; Niwa, T. Indoxyl sulfate promotes vascular smooth muscle cell senescence with upregulation of p53, p21, and prelamin A through oxidative stress. Am. J. Physiol. Cell Physiol. 2012, 303, C126-C134. [CrossRef]

204. Adelibieke, Y.; Yisireyili, M.; Ng, H.-Y.; Saito, S.; Nishijima, F.; Niwa, T. Indoxyl sulfate induces IL-6 expression in vascular endothelial and smooth muscle cells through OAT3-mediated uptake and activation of AhR/NF-kB pathway. Nephron Exp. Nephrol. 2014, 128, 1-8. [CrossRef] [PubMed]

205. Yisireyili, M.; Saito, S.; Abudureyimu, S.; Adelibieke, Y.; Ng, H.-Y.; Nishijima, F.; Takeshita, K.; Murohara, T.; Niwa, T. Indoxyl sulfate-induced activation of (pro)renin receptor promotes cell proliferation and tissue factor expression in vascular smooth muscle cells. PLoS ONE 2014, 9, e109268. [CrossRef] [PubMed] 
206. Yamamoto, H.; Tsuruoka, S.; Ioka, T.; Ando, H.; Ito, C.; Akimoto, T.; Fujimura, A.; Asano, Y.; Kusano, E. Indoxyl sulfate stimulates proliferation of rat vascular smooth muscle cells. Kidney Int. 2006, 69, 1780-1785. [CrossRef] [PubMed]

207. Ng, H.-Y.; Bolati, W.; Lee, C.-T.; Chien, Y.-S.; Yisireyili, M.; Saito, S.; Pei, S.-N.; Nishijima, F.; Niwa, T. Indoxyl Sulfate Downregulates Mas Receptor via Aryl Hydrocarbon Receptor/Nuclear Factor-kappa B, and Induces Cell Proliferation and Tissue Factor Expression in Vascular Smooth Muscle Cells. Nephron 2016, 133, $205-212$. [CrossRef] [PubMed]

208. Shimizu, H.; Hirose, Y.; Nishijima, F.; Tsubakihara, Y.; Miyazaki, H. ROS and PDGF-beta [corrected] receptors are critically involved in indoxyl sulfate actions that promote vascular smooth muscle cell proliferation and migration. Am. J. Physiol. Cell Physiol. 2009, 297, C389-C396. [CrossRef]

209. Shimizu, H.; Hirose, Y.; Goto, S.; Nishijima, F.; Zrelli, H.; Zghonda, N.; Niwa, T.; Miyazaki, H. Indoxyl sulfate enhances angiotensin II signaling through upregulation of epidermal growth factor receptor expression in vascular smooth muscle cells. Life Sci. 2012, 91, 172-177. [CrossRef]

210. Taki, K.; Tsuruta, Y.; Niwa, T. Indoxyl sulfate and atherosclerotic risk factors in hemodialysis patients. Am. J. Nephrol. 2007, 27, 30-35. [CrossRef]

211. Parhami, F.; Tintut, Y.; Ballard, A.; Fogelman, A.M.; Demer, L.L. Leptin enhances the calcification of vascular cells: Artery wall as a target of leptin. Circ. Res. 2001, 88, 954-960. [CrossRef]

212. Dubey, L.; Hesong, Z. Role of leptin in atherogenesis. Exp. Clin. Cardiol. 2006, 11, $269-275$.

213. Zeadin, M.G.; Butcher, M.K.; Shaughnessy, S.G.; Werstuck, G.H. Leptin promotes osteoblast differentiation and mineralization of primary cultures of vascular smooth muscle cells by inhibiting glycogen synthase kinase (GSK)-3ß. Biochem. Biophys. Res. Commun. 2012, 425, 924-930. [CrossRef]

214. Zeadin, M.; Butcher, M.; Werstuck, G.; Khan, M.; Yee, C.K.; Shaughnessy, S.G. Effect of leptin on vascular calcification in apolipoprotein E-deficient mice. Arterioscler. Thromb. Vasc. Biol. 2009, 29, 2069-2075. [CrossRef] [PubMed]

215. Chen, N.X.; O'Neill, K.; Akl, N.K.; Moe, S.M. Adipocyte induced arterial calcification is prevented with sodium thiosulfate. Biochem. Biophys. Res. Commun. 2014, 449, 151-156. [CrossRef] [PubMed]

216. Iribarren, C.; Husson, G.; Go, A.S.; Lo, J.C.; Fair, J.M.; Rubin, G.D.; Hlatky, M.A.; Fortmann, S.P. Plasma leptin levels and coronary artery calcification in older adults. J. Clin. Endocrinol. Metab. 2007, 92, 729-732. [CrossRef] [PubMed]

217. Szulc, P.; Amri, E.Z.; Varennes, A.; Panaia-Ferrari, P.; Fontas, E.; Goudable, J.; Chapurlat, R.; Breuil, V. Positive Association of High Leptin Level and Abdominal Aortic Calcification in Men-The Prospective MINOS Study. Circ. J. 2018, 82, 2954-2961. [CrossRef] [PubMed]

218. De Oliveira, R.B.; Liabeuf, S.; Okazaki, H.; Lenglet, A.; Desjardins, L.; Lemke, H.-D.; Vanholder, R.; Choukroun, G.; Massy, Z.A.; European Uremic Toxin Work Group (EUTox). The clinical impact of plasma leptin levels in a cohort of chronic kidney disease patients. Clin. Kidney J. 2013, 6, 63-70. [CrossRef]

219. Reilly, M.P.; Iqbal, N.; Schutta, M.; Wolfe, M.L.; Scally, M.; Localio, A.R.; Rader, D.J.; Kimmel, S.E. Plasma leptin levels are associated with coronary atherosclerosis in type 2 diabetes. J. Clin. Endocrinol. Metab. 2004, 89, 3872-3878. [CrossRef]

220. Liu, G.-Y.; Liang, Q.-H.; Cui, R.-R.; Liu, Y.; Wu, S.-S.; Shan, P.-F.; Yuan, L.-Q.; Liao, E.-Y. Leptin promotes the osteoblastic differentiation of vascular smooth muscle cells from female mice by increasing RANKL expression. Endocrinology 2014, 155, 558-567. [CrossRef]

221. Li, L.; Mamputu, J.-C.; Wiernsperger, N.; Renier, G. Signaling pathways involved in human vascular smooth muscle cell proliferation and matrix metalloproteinase-2 expression induced by leptin: Inhibitory effect of metformin. Diabetes 2005, 54, 2227-2234. [CrossRef]

222. Ghantous, C.M.; Azrak, Z.; Hanache, S.; Abou-Kheir, W.; Zeidan, A. Differential Role of Leptin and Adiponectin in Cardiovascular System. Int. J. Endocrinol. 2015, 2015. [CrossRef]

223. Huang, F.; Xiong, X.; Wang, H.; You, S.; Zeng, H. Leptin-induced vascular smooth muscle cell proliferation via regulating cell cycle, activating ERK1/2 and NF-kappaB. Acta Biochim. Biophys. Sin. 2010, 42, 325-331. [CrossRef]

224. Liu, W.; Zhu, S.; Chen, Y.; Wu, X.; Ni, W.; Chen, Y.; Zhao, L. The effects of leptin on apoptosis of airway smooth muscle cells via the PI3K/Akt signaling pathway. Zhonghua Jie He He Hu Xi Za Zhi 2012, 35, 915-918. [PubMed] 
225. Schroeter, M.R.; Leifheit-Nestler, M.; Hubert, A.; Schumann, B.; Glückermann, R.; Eschholz, N.; Krüger, N.; Lutz, S.; Hasenfuss, G.; Konstantinides, S.; et al. Leptin promotes neointima formation and smooth muscle cell proliferation via NADPH oxidase activation and signalling in caveolin-rich microdomains. Cardiovasc. Res. 2013, 99, 555-565. [CrossRef] [PubMed]

226. Bohlen, F.; Kratzsch, J.; Mueller, M.; Seidel, B.; Friedman-Einat, M.; Witzigmann, H.; Teupser, D.; Koerner, A.; Storck, M.; Thiery, J. Leptin inhibits cell growth of human vascular smooth muscle cells. Vasc. Pharmacol. 2007, 46, 67-71. [CrossRef] [PubMed]

227. Oda, A.; Taniguchi, T.; Yokoyama, M. Leptin stimulates rat aortic smooth muscle cell proliferation and migration. Kobe J. Med. Sci. 2001, 47, 141-150. [CrossRef]

228. Tsai, Y.-C.; Leu, S.-Y.; Peng, Y.-J.; Lee, Y.-M.; Hsu, C.-H.; Chou, S.-C.; Yen, M.-H.; Cheng, P.-Y. Genistein suppresses leptin-induced proliferation and migration of vascular smooth muscle cells and neointima formation. J. Cell. Mol. Med. 2017, 21, 422-431. [CrossRef] [PubMed]

229. Schneiderman, J.; Schaefer, K.; Kolodgie, F.D.; Savion, N.; Kotev-Emeth, S.; Dardik, R.; Simon, A.J.; Halak, M.; Pariente, C.; Engelberg, I.; et al. Leptin locally synthesized in carotid atherosclerotic plaques could be associated with lesion instability and cerebral emboli. J. Am. Heart Assoc. 2012, 1, e001727. [CrossRef]

230. Wang, Z.; Jiang, Y.; Liu, N.; Ren, L.; Zhu, Y.; An, Y.; Chen, D. Advanced glycation end-product $\mathrm{N} \varepsilon$-carboxymethyl-Lysine accelerates progression of atherosclerotic calcification in diabetes. Atherosclerosis 2012, 221, 387-396. [CrossRef]

231. Li, L.H.; Ye, F.; Fu, X.L.; Xu, S.N.; Bao, Z.Y.; Sun, Z.; Yan, J.C.; Wu, J.N.; Wang, Z.Q. Association between serum $\mathrm{N} \varepsilon$-carboxymethyl-lysine level and anterior tibial arterial plaque calcification in patients with diabetic foot post foot amputation. Zhonghua Xin Xue Guan Bing Za Zhi 2017, 45, 958-962. [CrossRef]

232. Kislinger, T.; Fu, C.; Huber, B.; Qu, W.; Taguchi, A.; Du Yan, S.; Hofmann, M.; Yan, S.F.; Pischetsrieder, M.; Stern, D.; et al. N(epsilon)-(carboxymethyl)lysine adducts of proteins are ligands for receptor for advanced glycation end products that activate cell signaling pathways and modulate gene expression. J. Biol. Chem. 1999, 274, 31740-31749. [CrossRef]

233. Meloche, J.; Paulin, R.; Courboulin, A.; Lambert, C.; Barrier, M.; Bonnet, P.; Bisserier, M.; Roy, M.; Sussman, M.A.; Agharazii, M.; et al. RAGE-Dependent Activation of the Oncoprotein Pim1 Plays a Critical Role in Systemic Vascular Remodeling Processes. Arterioscler. Thromb. Vasc. Biol. 2011, 31, $2114-2124$. [CrossRef]

234. Liabeuf, S.; Barreto, D.V.; Barreto, F.C.; Meert, N.; Glorieux, G.; Schepers, E.; Temmar, M.; Choukroun, G.; Vanholder, R.; Massy, Z.A.; et al. Free p-cresylsulphate is a predictor of mortality in patients at different stages of chronic kidney disease. Nephrol. Dial. Transplant. 2010, 25, 1183-1191. [CrossRef] [PubMed]

235. Watanabe, H.; Miyamoto, Y.; Enoki, Y.; Ishima, Y.; Kadowaki, D.; Kotani, S.; Nakajima, M.; Tanaka, M.; Matsushita, K.; Mori, Y.; et al. p-Cresyl sulfate, a uremic toxin, causes vascular endothelial and smooth muscle cell damages by inducing oxidative stress. Pharmacol. Res. Perspect. 2015, 3, e00092. [CrossRef] [PubMed]

236. Gross, P.; Massy, Z.A.; Henaut, L.; Boudot, C.; Cagnard, J.; March, C.; Kamel, S.; Drueke, T.B.; Six, I. Para-cresyl sulfate acutely impairs vascular reactivity and induces vascular remodeling. J. Cell. Physiol. 2015, 230, 2927-2935. [CrossRef] [PubMed]

237. Han, H.; Chen, Y.; Zhu, Z.; Su, X.; Ni, J.; Du, R.; Zhang, R.; Jin, W. p-Cresyl sulfate promotes the formation of atherosclerotic lesions and induces plaque instability by targeting vascular smooth muscle cells. Front. Med. 2016, 10, 320-329. [CrossRef] [PubMed]

238. Guo, J.; Lu, L.; Hua, Y.; Huang, K.; Wang, I.; Huang, L.; Fu, Q.; Chen, A.; Chan, P.; Fan, H.; et al. Vasculopathy in the setting of cardiorenal syndrome: Roles of protein-bound uremic toxins. Am. J. Physiol. Heart Circ. Physiol. 2017, 313, H1-H13. [CrossRef]

239. Ciceri, P.; Volpi, E.; Brenna, I.; Elli, F.; Borghi, E.; Brancaccio, D.; Cozzolino, M. The combination of lanthanum chloride and the calcimimetic calindol delays the progression of vascular smooth muscle cells calcification. Biochem. Biophys. Res. Commun. 2012, 418, 770-773. [CrossRef]

240. Sinha-Hikim, I.; Shen, R.; Paul Lee, W.-N.N.; Crum, A.; Vaziri, N.D.; Norris, K.C. Effects of a novel cystine-based glutathione precursor on oxidative stress in vascular smooth muscle cells. Am. J. Physiol. Cell Physiol. 2010, 299, C638-C642. [CrossRef] 
241. Facchiano, F.; D’Arcangelo, D.; Riccomi, A.; Lentini, A.; Beninati, S.; Capogrossi, M.C. Transglutaminase activity is involved in polyamine-induced programmed cell death. Exp. Cell Res. 2001, 271, 118-129. [CrossRef]

242. Sinha-Hikim, I.; Shen, R.; Kovacheva, E.; Crum, A.; Vaziri, N.D.; Norris, K.C. Inhibition of apoptotic signalling in spermine-treated vascular smooth muscle cells by a novel glutathione precursor. Cell Biol. Int. 2010, 34, 503-511. [CrossRef]

243. Nishida, K.; Abiko, T.; Ishihara, M.; Tomikawa, M. Arterial injury-induced smooth muscle cell proliferation in rats is accompanied by increase in polyamine synthesis and level. Atherosclerosis 1990, 83, 119-125. [CrossRef]

244. Zhu, L.; Xiao, R.; Zhang, X.; Lang, Y.; Liu, F.; Yu, Z.; Zhang, J.; Su, Y.; Lu, Y.; Wang, T.; et al. Spermine on Endothelial Extracellular Vesicles Mediates Smoking-Induced Pulmonary Hypertension Partially Through Calcium-Sensing Receptor. Arterioscler. Thromb. Vasc. Biol. 2019, 39, 482-495. [CrossRef] [PubMed]

245. Wei, C.; Li, H.-Z.; Wang, Y.-H.; Peng, X.; Shao, H.-J.; Li, H.-X.; Bai, S.-Z.; Lu, X.-X.; Wu, L.-Y.; Wang, R.; et al. Exogenous spermine inhibits the proliferation of human pulmonary artery smooth muscle cells caused by chemically-induced hypoxia via the suppression of the ERK1/2- and PI3K/AKT-associated pathways. Int. J. Mol. Med. 2016, 37, 39-46. [CrossRef] [PubMed]

246. Schepers, E.; Glorieux, G.; Dou, L.; Cerini, C.; Gayrard, N.; Louvet, L.; Maugard, C.; Preus, P.; Rodriguez-Ortiz, M.; Argiles, A.; et al. Guanidino compounds as cause of cardiovascular damage in chronic kidney disease: An in vitro evaluation. Blood Purif. 2010, 30, 277-287. [CrossRef] [PubMed]

247. Jang, J.J.; Berkheimer, S.B.; Merchant, M.; Krishnaswami, A. Asymmetric dimethylarginine and coronary artery calcium scores are increased in patients infected with human immunodeficiency virus. Atherosclerosis 2011, 217, 514-517. [CrossRef] [PubMed]

248. Iribarren, C.; Husson, G.; Sydow, K.; Wang, B.-Y.; Sidney, S.; Cooke, J.P. Asymmetric dimethyl-arginine and coronary artery calcification in young adults entering middle age: The CARDIA Study. Eur. J. Cardiovasc. Prev. Rehabil. 2007, 14, 222-229. [CrossRef] [PubMed]

249. Kobayashi, S.; Oka, M.; Maesato, K.; Ikee, R.; Mano, T.; Hidekazu, M.; Ohtake, T. Coronary Artery Calcification, ADMA, and Insulin Resistance in CKD Patients. CJASN 2008, 3, 1289-1295. [CrossRef]

250. Kiani, A.N.; Mahoney, J.A.; Petri, M. Asymmetric dimethylarginine is a marker of poor prognosis and coronary calcium in systemic lupus erythematosus. J. Rheumatol. 2007, 34, 1502-1505.

251. Krzanowski, M.; Krzanowska, K.; Gajda, M.; Dumnicka, P.; Kopeć, G.; Guzik, B.; Woziwodzka, K.; Dziewierz, A.; Litwin, J.A.; Sułowicz, W. Asymmetric dimethylarginine as a useful risk marker of radial artery calcification in patients with advanced kidney disease. Pol. Arch. Intern. Med. 2018, 128, 157-165. [CrossRef]

252. Coen, G.; Mantella, D.; Sardella, D.; Beraldi, M.P.; Ferrari, I.; Pierantozzi, A.; Lippi, B.; Di Giulio, S. Asymmetric dimethylarginine, vascular calcifications and parathyroid hormone serum levels in hemodialysis patients. J. Nephrol. 2009, 22, 616-622.

253. Yuan, Q.; Jiang, D.-J.; Chen, Q.-Q.; Wang, S.; Xin, H.-Y.; Deng, H.-W.; Li, Y.-J. Role of asymmetric dimethylarginine in homocysteine-induced apoptosis of vascular smooth muscle cells. Biochem. Biophys. Res. Commun. 2007, 356, 880-885. [CrossRef]

254. Pekarova, M.; Koudelka, A.; Kolarova, H.; Ambrozova, G.; Klinke, A.; Cerna, A.; Kadlec, J.; Trundova, M.; Sindlerova Svihalkova, L.; Kuchta, R.; et al. Asymmetric dimethyl arginine induces pulmonary vascular dysfunction via activation of signal transducer and activator of transcription 3 and stabilization of hypoxia-inducible factor 1-alpha. Vasc. Pharmacol. 2015, 73, 138-148. [CrossRef] [PubMed]

255. Li, X.-H.; Peng, J.; Tan, N.; Wu, W.-H.; Li, T.-T.; Shi, R.-Z.; Li, Y.-J. Involvement of asymmetric dimethylarginine and Rho kinase in the vascular remodeling in monocrotaline-induced pulmonary hypertension. Vasc. Pharmacol. 2010, 53, 223-229. [CrossRef] [PubMed]

256. Zhou, Y.; Lan, X.; Guo, H.; Zhang, Y.; Ma, L.; Cao, J. Rho/ROCK signal cascade mediates asymmetric dimethylarginine-induced vascular smooth muscle cells migration and phenotype change. Biomed. Res. Int. 2014, 2014. [CrossRef] [PubMed]

257. Sun, L.; Zhang, T.; Yu, X.; Xin, W.; Lan, X.; Zhang, D.; Huang, C.; Du, G. Asymmetric dimethylarginine confers the communication between endothelial and smooth muscle cells and leads to VSMC migration through p38 and ERK1/2 signaling cascade. FEBS Lett. 2011, 585, 2727-2734. [CrossRef] [PubMed] 
258. Alesutan, I.; Musculus, K.; Castor, T.; Alzoubi, K.; Voelkl, J.; Lang, F. Inhibition of Phosphate-Induced Vascular Smooth Muscle Cell Osteo-/Chondrogenic Signaling and Calcification by Bafilomycin A1 and Methylamine. Kidney Blood Press. Res. 2015, 40, 490-499. [CrossRef] [PubMed]

259. Hernandez, M.; Solé, M.; Boada, M.; Unzeta, M. Soluble semicarbazide sensitive amine oxidase (SSAO) catalysis induces apoptosis in vascular smooth muscle cells. Biochim. Biophys. Acta 2006, 1763, 164-173. [CrossRef]

260. Hao, W.; Yang, R.; Yang, Y.; Jin, S.; Li, Y.; Yuan, F.; Guo, Q.; Xiao, L.; Wang, X.; Wang, F.; et al. Stellate ganglion block ameliorates vascular calcification by inhibiting endoplasmic reticulum stress. Life Sci. 2018, 193, 1-8. [CrossRef]

261. Jiao, L.; Wang, M.-C.; Yang, Y.-A.; Chen, E.-Q.; Xu, H.-T.; Wu, K.-Y.; Zhang, S.-M. Norepinephrine reversibly regulates the proliferation and phenotypic transformation of vascular smooth muscle cells. Exp. Mol. Pathol. 2008, 85, 196-200. [CrossRef]

262. Luo, Q.; Wang, X.; Liu, R.; Qiao, H.; Wang, P.; Jiang, C.; Zhang, Q.; Cao, Y.; Yu, H.; Qu, L. alpha1A-adrenoceptor is involved in norepinephrine-induced proliferation of pulmonary artery smooth muscle cells via CaMKII signaling. J. Cell. Biochem. 2019, 120, 9345-9355. [CrossRef]

263. Bell, L.; Madri, J.A. Effect of platelet factors on migration of cultured bovine aortic endothelial and smooth muscle cells. Circ. Res. 1989, 65, 1057-1065. [CrossRef]

264. Zhang, H.; Facemire, C.S.; Banes, A.J.; Faber, J.E. Different alpha-adrenoceptors mediate migration of vascular smooth muscle cells and adventitial fibroblasts in vitro. Am. J. Physiol. Heart Circ. Physiol. 2002, 282, H2364-H2370. [CrossRef] [PubMed]

265. Zhang, X.; Li, Y.; Yang, P.; Liu, X.; Lu, L.; Chen, Y.; Zhong, X.; Li, Z.; Liu, H.; Ou, C.; et al. Trimethylamine-N-Oxide Promotes Vascular Calcification Through Activation of NLRP3 (Nucleotide-Binding Domain, Leucine-Rich-Containing Family, Pyrin Domain-Containing-3) Inflammasome and NF- $\mathrm{kB}$ (Nuclear Factor $\mathrm{kB}$ ) Signals. Arterioscler. Thromb. Vasc. Biol. 2020, 40, 751-765. [CrossRef] [PubMed]

266. Meyer, K.A.; Benton, T.Z.; Bennett, B.J.; Jacobs, D.R.; Lloyd-Jones, D.M.; Gross, M.D.; Carr, J.J.; Gordon-Larsen, P.; Zeisel, S.H. Microbiota-Dependent Metabolite Trimethylamine N-Oxide and Coronary Artery Calcium in the Coronary Artery Risk Development in Young Adults Study (CARDIA). J. Am. Heart Assoc. 2016, 5, e003970. [CrossRef] [PubMed]

267. Seldin, M.M.; Meng, Y.; Qi, H.; Zhu, W.; Wang, Z.; Hazen, S.L.; Lusis, A.J.; Shih, D.M. Trimethylamine $\mathrm{N}$-Oxide Promotes Vascular Inflammation through Signaling of Mitogen-Activated Protein Kinase and Nuclear Factor-кB. J. Am. Heart Assoc. 2016, 5, e002767. [CrossRef]

268. Song, Z.; Zhao, Y.; Wang, X.; Xu, M.-J. Secondary hyperuricemia in chronic renal failure promotes vascular calcification in rats. Sheng Li Xue Bao 2016, 68, 709-715.

269. Yan, B.; Liu, D.; Zhu, J.; Pang, X. The effects of hyperuricemia on the differentiation and proliferation of osteoblasts and vascular smooth muscle cells are implicated in the elevated risk of osteopenia and vascular calcification in gout: An in vivo and in vitro analysis. J. Cell. Biochem. 2019, 120, 19660-19672. [CrossRef]

270. Jun, J.E.; Lee, Y.-B.; Lee, S.-E.; Ahn, J.Y.; Kim, G.; Jin, S.-M.; Hur, K.Y.; Lee, M.-K.; Kang, M.R.; Kim, J.H. Elevated serum uric acid predicts the development of moderate coronary artery calcification independent of conventional cardiovascular risk factors. Atherosclerosis 2018, 272, 233-239. [CrossRef]

271. Grossman, C.; Shemesh, J.; Koren-Morag, N.; Bornstein, G.; Ben-Zvi, I.; Grossman, E. Serum uric acid is associated with coronary artery calcification. J. Clin. Hypertens. 2014, 16, 424-428. [CrossRef]

272. Calvo, R.Y.; Araneta, M.R.G.; Kritz-Silverstein, D.; Laughlin, G.A.; Barrett-Connor, E. Relation of serum uric acid to severity and progression of coronary artery calcium in postmenopausal White and Filipino women (from the Rancho Bernardo study). Am. J. Cardiol. 2014, 113, 1153-1158. [CrossRef]

273. D’Marco, L.; García, I.; Vega, C. Uric acid, atherosclerosis and vascular calcifications in chronic kidney disease. Investig. Clin. 2012, 53, 52-59.

274. Malik, R.; Aneni, E.C.; Shahrayar, S.; Freitas, W.M.; Ali, S.S.; Veledar, E.; Latif, M.A.; Aziz, M.; Ahmed, R.; Khan, S.A.; et al. Elevated serum uric acid is associated with vascular inflammation but not coronary artery calcification in the healthy octogenarians: The Brazilian study on healthy aging. Aging Clin. Exp. Res. 2016, 28, 359-362. [CrossRef] [PubMed]

275. Corry, D.B.; Eslami, P.; Yamamoto, K.; Nyby, M.D.; Makino, H.; Tuck, M.L. Uric acid stimulates vascular smooth muscle cell proliferation and oxidative stress via the vascular renin-angiotensin system. J. Hypertens. 2008, 26, 269-275. [CrossRef] [PubMed] 
276. Tang, L.; Xu, Y.; Wei, Y.; He, X. Uric acid induces the expression of TNF- $\alpha$ via the ROS-MAPK-NF- $\kappa B$ signaling pathway in rat vascular smooth muscle cells. Mol. Med. Rep. 2017, 16, 6928-6933. [CrossRef] [PubMed]

277. Oğuz, N.; Kırça, M.; Çetin, A.; Yeşilkaya, A. Effect of uric acid on inflammatory COX-2 and ROS pathways in vascular smooth muscle cells. J. Recept. Signal Transduct. 2017, 37, 500-505. [CrossRef] [PubMed]

278. Dai, Y.; Cao, Y.; Zhang, Z.; Vallurupalli, S.; Mehta, J.L. Xanthine Oxidase Induces Foam Cell Formation through LOX-1 and NLRP3 Activation. Cardiovasc. Drugs Ther. 2017, 31, 19-27. [CrossRef]

279. Fu, X.; Niu, N.; Li, G.; Xu, M.; Lou, Y.; Mei, J.; Liu, Q.; Sui, Z.; Sun, J.; Qu, P. Blockage of macrophage migration inhibitory factor (MIF) suppressed uric acid-induced vascular inflammation, smooth muscle cell de-differentiation, and remodeling. Biochem. Biophys. Res. Commun. 2019, 508, 440-444. [CrossRef]

280. Rao, G.N.; Corson, M.A.; Berk, B.C. Uric acid stimulates vascular smooth muscle cell proliferation by increasing platelet-derived growth factor A-chain expression. J. Biol. Chem. 1991, 266, 8604-8608.

281. Kırça, M.; Oğuz, N.; Çetin, A.; Uzuner, F.; Yeşilkaya, A. Uric acid stimulates proliferative pathways in vascular smooth muscle cells through the activation of p38 MAPK, p44/42 MAPK and PDGFR $\beta$. J. Recept. Signal Transduct. Res. 2017, 37, 167-173. [CrossRef]

282. Kang, D.-H.; Park, S.-K.; Lee, I.-K.; Johnson, R.J. Uric acid-induced C-reactive protein expression: Implication on cell proliferation and nitric oxide production of human vascular cells. J. Am. Soc. Nephrol. 2005, 16, 3553-3562. [CrossRef]

283. Krohn, J.B.; Hutcheson, J.D.; Martínez-Martínez, E.; Aikawa, E. Extracellular vesicles in cardiovascular calcification: Expanding current paradigms. J. Physiol. 2016, 594, 2895-2903. [CrossRef]

284. Pfaltzgraff, E.R.; Bader, D.M. Heterogeneity in vascular smooth muscle cell embryonic origin in relation to adult structure, physiology, and disease. Dev. Dyn. 2015, 244, 410-416. [CrossRef] [PubMed]

285. Gayrard, N.; Muyor, K.; Notarnicola, C.; Duranton, F.; Jover, B.; Argilés, À. Optimisation of cell and ex vivo culture conditions to study vascular calcification. PLoS ONE 2020, 15, e0230201. [CrossRef] [PubMed]

286. Cohen, G.; Glorieux, G.; Thornalley, P.; Schepers, E.; Meert, N.; Jankowski, J.; Jankowski, V.; Argiles, A.; Anderstam, B.; Brunet, P.; et al. Review on uraemic toxins III: Recommendations for handling uraemic retention solutes in vitro-Towards a standardized approach for research on uraemia. Nephrol. Dial. Transplant. 2007, 22, 3381-3390. [CrossRef] [PubMed]

287. Lai, P.C.; Huang, L.L.; Panrucker, D.E.; Church, R.B.; Lorscheider, F.L. Distribution of bovine fetuin and albumin in plasma, allantoic and amniotic fluids during development. J. Reprod. Fertil. 1981, 63, 53-60. [CrossRef] [PubMed]

288. Häusler, M.; Schäfer, C.; Osterwinter, C.; Jahnen-Dechent, W. The Physiologic Development of Fetuin-A Serum Concentrations in Children. Pediatr. Res. 2009, 66, 660-664. [CrossRef]

289. Basnakian, A.G.; Shah, S.V.; Ok, E.; Altunel, E.; Apostolov, E.O. Carbamylated LDL. Adv. Clin. Chem. 2010, 51, 25-52. [CrossRef]

290. Shah, S.V.; Shukla, A.M.; Bose, C.; Basnakian, A.G.; Rajapurkar, M. Recent advances in understanding the pathogenesis of atherosclerosis in CKD patients. J. Ren. Nutr. 2015, 25, 205-208. [CrossRef]

291. Hawkins, C.L. Protein carbamylation: A key driver of vascular calcification during chronic kidney disease. Kidney Int. 2018, 94, 12-14. [CrossRef]

292. Kukla, A.; Adulla, M.; Pascual, J.; Samaniego, M.; Nanovic, L.; Becker, B.N.; Djamali, A. CKD stage-to-stage progression in native and transplant kidney disease. Nephrol. Dial. Transplant. 2008, 23, 693-700. [CrossRef]

293. Hill, A.B. The Environment and Disease: Association or Causation? Proc. R. Soc. Med. 1965, 58, $295-300$. [CrossRef]

294. Schantl, A.E.; Ivarsson, M.E.; Leroux, J.-C. Investigational Pharmacological Treatments for Vascular Calcification. Adv. Ther. 2019, 2, 1800094. [CrossRef]

295. Nelson, A.J.; Raggi, P.; Wolf, M.; Gold, A.M.; Chertow, G.M.; Roe, M.T. Targeting Vascular Calcification in Chronic Kidney Disease. J. Am. Coll. Cardiol. Basic Transl. Sci. 2020, 5, 398-412. [CrossRef] [PubMed]

296. Raggi, P.; Bellasi, A.; Bushinsky, D.; Bover, J.; Rodriguez, M.; Ketteler, M.; Sinha, S.; Salcedo, C.; Gillotti, K.; Padgett, C.; et al. Slowing Progression of Cardiovascular Calcification with SNF472 in Patients on Hemodialysis. Circulation 2020, 141, 728-739. [CrossRef] [PubMed]

297. Schurgers, L.J.; Cranenburg, E.C.M.; Vermeer, C. Matrix Gla-protein: The calcification inhibitor in need of vitamin K. Thromb. Haemost. 2008, 100, 593-603. [PubMed]

298. Dai, L.; Qureshi, A.R.; Witasp, A.; Lindholm, B.; Stenvinkel, P. Early Vascular Ageing and Cellular Senescence in Chronic Kidney Disease. Comput. Struct. Biotechnol. J. 2019, 17, 721-729. [CrossRef] [PubMed] 
299. Liu, Z.; Li, J.; Liu, H.; Tang, Y.; Zhan, Q.; Lai, W.; Ao, L.; Meng, X.; Ren, H.; Xu, D.; et al. The intestinal microbiota associated with cardiac valve calcification differs from that of coronary artery disease. Atherosclerosis 2019, 284, 121-128. [CrossRef]

300. Moludi, J.; Maleki, V.; Jafari-Vayghyan, H.; Vaghef-Mehrabany, E.; Alizadeh, M. Metabolic endotoxemia and cardiovascular disease: A systematic review about potential roles of prebiotics and probiotics. Clin. Exp. Pharmacol. Physiol. 2020, 47, 927-939. [CrossRef]

301. Willems, B.A.; Furmanik, M.; Caron, M.M.J.; Chatrou, M.L.L.; Kusters, D.H.M.; Welting, T.J.M.; Stock, M.; Rafael, M.S.; Viegas, C.S.B.; Simes, D.C.; et al. Ucma/GRP inhibits phosphate-induced vascular smooth muscle cell calcification via SMAD-dependent BMP signalling. Sci. Rep. 2018, 8, 1-11. [CrossRef]

302. Furmanik, M.; Chatrou, M.; van Gorp, R.H.; Akbulut, A.; Willems, B.; Schmidt, H.H.; van Eys, G.; Bochaton-Piallat, M.-L.; Proudfoot, D.; Biessen, E.A.; et al. Reactive Oxygen-Forming Nox5 Links Vascular Smooth Muscle Cell Phenotypic Switching and Extracellular Vesicle-Mediated Vascular Calcification. Circ. Res. 2020, 127, 911-927. [CrossRef]

303. Viegas Carla, S.B.; Santos, L.; Macedo Anjos, L.; Matos António, A.; Silva Ana, P.; Neves Pedro, L.; Staes, A.; Gevaert, K.; Morais, R.; Vermeer, C.; et al. Chronic Kidney Disease Circulating Calciprotein Particles and Extracellular Vesicles Promote Vascular Calcification. Arterioscler. Thromb. Vasc. Biol. 2018, 38, 575-587. [CrossRef]

304. EUTox the European Uremic Toxins (EUTox) Database. Available online: http://eutoxdb.odeesoft.com/home. php (accessed on 15 January 2019).

305. Duranton, F.; Cohen, G.; De Smet, R.; Rodriguez, M.; Jankowski, J.; Vanholder, R.; Argiles, A.; on behalf of the European Uremic Toxin Work Group. Normal and Pathologic Concentrations of Uremic Toxins. J. Am. Soc. Nephrol. 2012, 23, 1258-1270. [CrossRef] [PubMed]

(C) 2020 by the authors. Licensee MDPI, Basel, Switzerland. This article is an open access article distributed under the terms and conditions of the Creative Commons Attribution (CC BY) license (http://creativecommons.org/licenses/by/4.0/). 